\title{
Evaluation of Requirements and Efficiency \\ Parameters in the Use, Absorption, and Translocation of Nutrients in the Production of Hymenaea courbaril L. Seedlings, a Fruit Tree of Neotropical Importance
}

\author{
Layara Alexandre Bessa \\ Laboratory of Plant Mineral Nutrition, Instituto Federal Goiano - Rio Verde campus, \\ Rodovia Sul Goiana, Km 01, 75901-970, Rio Verde - GO, Brazil \\ E-mail: layara.bessa@ifgoiano.edu.br
}

Mateus Neri Oliveira Reis

Laboratory of Plant Mineral Nutrition, Instituto Federal Goiano - Rio Verde campus, Rodovia Sul Goiana, Km 01, 75901-970, Rio Verde - GO, Brazil

E-mail: mateusnerioliveira@ hotmail.com

\section{Luciana Cristina Vitorino (Corresponding author)}

Postgraduate Program in Biodiversity and Conservation, Instituto Federal Goiano, Rio Verde campus, Rodovia Sul Goiana, Km 01, 75901-970, Rio Verde - GO, Brazil

E-mail: luciana.vitorino@ifgoiano.edu.br

Fabiano Guimarães Silva

Laboratory of Tissue Culture, Instituto Federal Goiano - Rio Verde campus, Rodovia Sul Goiana, Km 01, 75901-970, Rio Verde - GO, Brazil

E-mail: fabiano.silva@ifgoiano.edu.br

Received: December 17, 2020

doi:10.5296/jas.v9i2.18089
Accepted: January 5, 2021 Published: January 25, 2021

URL: https://doi.org/10.5296/jas.v9i2.18089 


\section{Abstract}

The lack of sufficient knowledge on nutritional requirements, as well as efficiency parameters, in the use, absorption, and translocation of nutrients by seedlings in developmental stages may lead to the excessive use of chemical fertilizers, which end up contaminating the environment. Therefore, this research adopted the hydroponic system to elucidate the nutritional requirements of Hymenaea courbaril L. seedlings, a fruit tree of neotropical importance, throughout its development (30, 60, 90, 120, 150, and 180 days after transplantation). Consequently, biometric data on growth and mineral nutrition were obtained and utilized to determine efficiency parameters in the use, absorption, and translocation of nutrients. Although $H$. courbaril leaves functioned as efficient drains throughout the development, $\mathrm{S}$ and Fe accumulated in the roots, owing to their not very mobile nature. The macro and micronutrients that were accumulated the most in the tissues were $\mathrm{N}$ and $\mathrm{Mn}$, which even suggested a tendency for $H$. courbaril to tolerate Mn concentrations that are naturally toxic. The most efficient adoption was observed for the $\mathrm{S}$ and $\mathrm{Cu}$ nutrients, whereas the most efficiently absorbed nutrients were $\mathrm{N}$ (the macro and micronutrient with the greatest accumulation) and $\mathrm{Fe}$ (the second micronutrient with the greatest accumulation). However, the seedlings efficiently translocated $\mathrm{Ca}-\mathrm{N}$ and $\mathrm{Mn}$, i.e., the most accumulated nutrients. Positive effects on growth were correlated with increases in $\mathrm{P}, \mathrm{Ca}$, and $\mathrm{Mg}$ levels, thus signaling the importance of an optimal supply of these nutrients in obtaining healthy seedlings of this species. This work suggests that to obtain seedlings of $H$. courbaril in practice, the availability of $\mathrm{N}, \mathrm{Mn}, \mathrm{P}, \mathrm{Ca}$ and $\mathrm{Mg}$ should be reviewed.

Keywords: hydroponics, macronutrients, micronutrients, absorption, translocation of nutrients

\section{Introduction}

To supply a growing market, which aims to maintain the natural landscape and restoration of areas previously degraded, it is necessary to produce seedlings of native fruit species. This is associated with growing interest of food, cosmetic and pharmaceutical industries in native fruit properties (Silva et al., 2001; Bailão et al., 2015). However, the current obtention of seedlings occurs via the application of agricultural fertilizers, under the "response rate" approach that links the fertilizer application rate to the yield (Briat et al., 2020). However, this approach may lead to the application of excessive amounts of these inputs, which, may prove to be toxic to plants, because they favor the decrease in soil $\mathrm{pH}$, thus increasing the availability of heavy metals (Khan et al., 2018). In contrast, nutrients present in fertilizers may be carried by rainwater, which leads to an excessive increase in phosphate and nitrate compounds in shallow bodies of water, a process known as eutrophication (Conley et al., 2009). The impact of high fertilizer, mainly nitrogen, on the environment can be minimized by optimal agricultural practices, such as crop rotation, establishment of soil cover, and rationalization of chemical nutrient application (Verzeaux et al., 2017). Therefore, it is necessary to understand the nutritional requirements of species at different stages of their development, which avoids the unnecessary applications of chemical fertilizers. Hydroponic cultivation is a technique that allows the isolation of external factors such as physics, soil 
chemistry, control of essential nutrients, and supply of oxygen and water necessary for the full development of the plant (Wootton-Beard, 2019; Sousa et al., 2020). Therefore, this system can be adopted to understand aspects of the absorption, use, and impact of different nutrients throughout the development of plants. Consequently, it provide answers to questions, such as: What nutrient is most required in the early stages of the development of a native species? Which nutrient is the most efficient to use or absorb? The answers to these questions help avoid indiscriminate fertilization, unnecessary cultivation expenses, as well as environmental contamination.

This study sought to answer these questions for jatobá (Hymenaea courbaril L.), a fruit tree of the Caesalpiniaceae family that occurs naturally in most Brazilian states, in formations of the seasonal semi-deciduous forest type (Carvalho, 2003). The fruits of this species are currently required in the production of sweets, jellies, and liquors (Silva et al., 2001). Furthermore, Souza et al. (2017) demonstrated the possibility of obtaining bio-sorbents by adopting the bark of the fruits for the removal of $\mathrm{Pb}$ (II) and $\mathrm{Cd}$ (II) from aqueous solutions while Aguiar et al. (2010) evaluated the potential larvicide of these barks. However, the massive production of the seedlings of this species can help in the rejuvenation of biodiversity and restoration of native forest areas. Despite their properties and potential, the nutritional requirement curve for the seedling production of this species has not yet been determined and little is known about the efficiency of nutrients used, as well as its relationships with the growth parameters of this species. For native fruit seedlings to have vitality, establish themselves in the field on a large scale, and have the potential to withstand adverse conditions of biotic and abiotic stresses, it is necessary to know the adequate demand for each nutrient (Bessa et al., 2016).

As the amount of nutrients varies with the plant tissue and, theoretically, the concentration of a nutrient in a given plant tissue increases with a decrease in nutritional efficiency. Understanding the distribution and nutritional concentration in different plant components helps in defining management strategies, thus ensuring more sustainable crops (Medeiros et al., 2020). Therefore, this study evaluated the nutritional growth curve of $H$. courbaril seedlings as a function of the time of cultivation in the nutrient solution, thus providing evidence regarding the efficiency of nutritional use and efficiency in absorption, as well as the relationship of nutrient contents with growth parameters.

\section{Method}

\subsection{Obtaining Plant Material and Growing Conditions}

The experiment was conducted from July to December 2019 in the Vegetable Tissue Culture Laboratory of the Federal Institute of Goiás - Rio Verde Campus, with 17²48'15.9" S $50^{\circ} 54^{\prime} 19.5^{\prime \prime} \mathrm{W}$ geographical coordinates. The jatobá fruits were collected at the Varginha farm with 17²3'48.66" S - 5050'11.71" W geographical coordinates, located in the rural area of the Rio Verde municipality, in Goiás. Later, these fruits were washed and pulped manually in running water to obtain the seeds. Afterward, the seeds were subjected to dormancy treatment via mechanical scarification, which involved rubbing one side of the seeds in water sandpaper on the opposite side to the hilum until the tegument is visible. 
The seeds were then sown in plastic trays $(50 \times 35 \times 8 \mathrm{~cm})$ containing autoclaved sand as a substrate. At 60 days after sowing, when the seedlings had 4-6 defined leaves, they were transplanted into pots containing 8 liters of a nutrient solution with $1 / 2$ ionic strength of Hoagland \& Arnon solution (1950), after which they were left there for 30 days to adapt.

During the experiment, the plants were grown under a mean irradiation of $400 \mu \mathrm{mol} \cdot \mathrm{m}^{-2} \cdot \mathrm{s}^{-1}$, and the nutrient solution was maintained under constant aeration with compressed air. The $\mathrm{pH}$ was adjusted daily to $5.5 \pm 0.5$ with the addition of $\mathrm{HCl}$ or $\mathrm{NaOH}$ when necessary. The nutrition solution was always replaced, reaching the criterion of $30 \%$ depletion of the initial value of electrical conductivity.

The plants were then evaluated at 30,60,90,120, 150, and 180 days after transplantation (DAT), after which biometric growth and nutritional data were obtained. The data were obtained by observing 08 repetitions per evaluation, considering each repetition as an $8 \mathrm{~L}$ pot of the nutrition solution containing two plants. The experiment was conducted in randomized blocks, with each treatment at a sampling period of a 30-day interval from the day the seedlings were transplanted.

\subsection{Biometric Evaluations}

In each evaluation period, the plants were collected and growth was determined by the following characteristics: stem length $(\mathrm{cm})$, stem diameter $(\mathrm{cm})$, number of leaves, length of the largest root $(\mathrm{cm})$, and number of nodes. The leaves were then separated and the leaf area $\left(\mathrm{cm}^{2}\right)$ was evaluated using the ImageJ® software (Rueden et al., 2017).

\subsection{Dry Mass and Nutritional Content}

In the different evaluation periods, the plants were harvested and separated into leaves, stems, and roots. The parts were dried in a greenhouse with forced air circulation at $65{ }^{\circ} \mathrm{C}$, until a constant dry mass, and then weighed to obtain the dry matter mass $(\mathrm{g})$. Subsequently, the macro $(\mathrm{N}, \mathrm{K}, \mathrm{Ca}, \mathrm{Mg}, \mathrm{P}$, and $\mathrm{S}$ ) and micronutrient (Fe, B, Mn, Zn, and $\mathrm{Cu}$ ) contents of the samples were determined according to the methodology proposed by Malavolta (1997). The nutrient content $(\mathrm{NC})$ was calculated from the ratio of dry matter $(\mathrm{g})$ and nutritional content $\left(\mathrm{g} \cdot \mathrm{kg}^{-1}\right)$.

\section{$\mathrm{NC}=$ Dry mass produced $(\mathrm{g}) \times$ Nutrient content $\left(\mathrm{g}^{*} \mathrm{~kg}^{-1}\right)$ Eq.1}

\subsection{Efficiency in the Use, Translocation, and Absorption of Nutrients}

The efficiencies were calculated from the nutritional content $(\mathrm{mg})$ and dry matter $(\mathrm{g})$. The nutrient use efficiency (NUE), which indicates the plant's capacity to convert the absorbed nutrient into the entirely dry matter was evaluated according to Siddiqi \& Glass (1981). The nutrient absorption efficiency (NAE) was calculated according to Swiader et al. (1994), where NAE indicates the capacity of the plant to absorb the available nutrients. Finally, the nutrient translocation efficiency (NTE) was calculated according to the equation of Li et al. (1991), which indicates the capacity of the plant to transport nutrients from the root to the air. 


$$
\begin{array}{lc}
\text { NUE }\left(\mathrm{g}^{2} \mathrm{mg}^{-1}\right)=\frac{\text { Total dry mass produced } \mathrm{d}^{\mathrm{T}}(\mathrm{g})}{\text { Total nutrient content in the plant (mg) }} & \text { Eq. } 2 \\
\text { NAE }\left(\mathrm{mg} \cdot \mathrm{g}^{-1}\right)=\frac{\text { Total nutrient content in the plant (mg) }}{\text { dry root mass (g) }} & \text { Eq. } 3 \\
\text { NTE }(\%)=\frac{\text { Shoot nutrient content (mg) }}{\text { Total nutrient content in the plant (mg) }} & \text { Eq. } 4
\end{array}
$$

\subsection{Statistical Analysis}

The data were subjected to ANOVA and regression analyses. The regression models were selected using the largest coefficients of determination and by determining the significance of the regression coefficients with a t-test at a $5 \%$ probability level. Correlation networks were obtained for the total nutrition content data and also for the biometric growth data associated with the nutrition levels. The nets were obtained via the "Qgraph" package (Epskamp et al., 2012). Alternatively, all variables were jointly evaluated by a Pearson correlation matrix using the "Corrplot" package (Wei et al., 2017). The strength of the relationship was analyzed via $\mathrm{r}$ values and the $5 \%$ probability significance of interaction. Statistical tests were performed in the R version 4.0.0 (R Core Team, 2020) environment.

\section{Results}

\subsection{Mass of Dry Matter}

H. courbaril seedlings accumulated biomass linearly over all evaluated periods. Therefore, at 180 DAT, the highest mean dry matter for leaves, stem, and roots $(8.77,7.67$, and $3.07 \mathrm{~g}$. plant $\left.^{-1}\right)$ were observed, whereas at 30 DAT, the lowest dry matter yields were observed $(2.38$, 1.32, and $0.69 \mathrm{~g} \cdot$ plant $\left.^{-1}\right)$, as shown in Figure 1. 


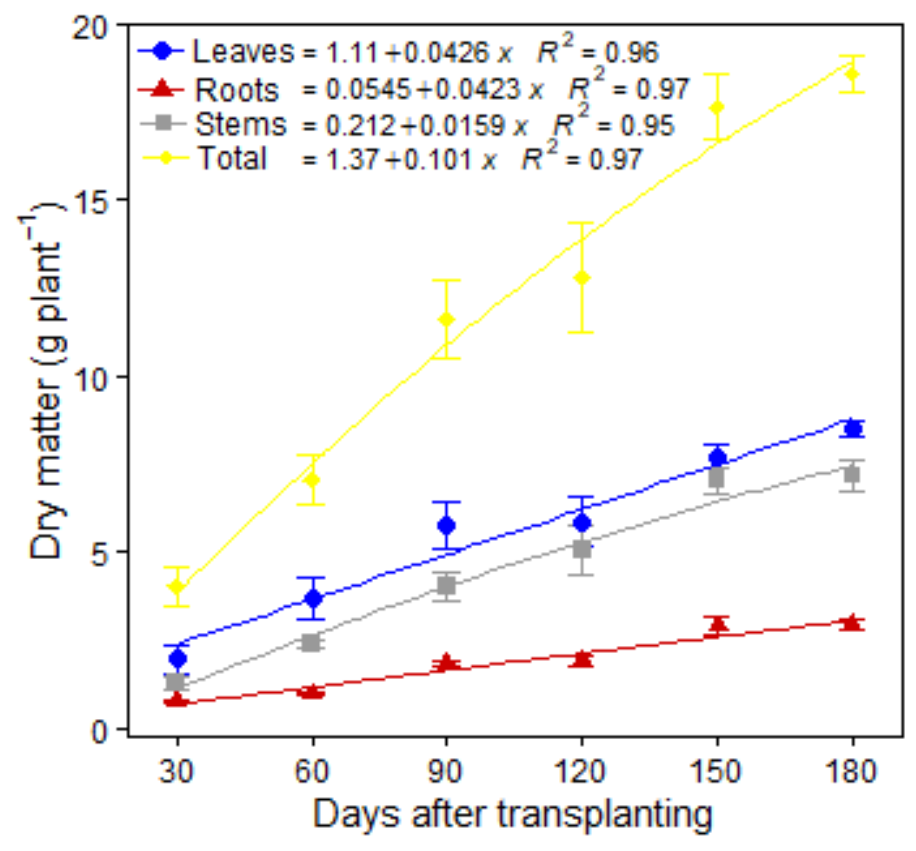

Figure 1. Masses of leaf dry matter, stem dry matter, root dry matter, and totally dry matter of jatobá seedlings (Hymenea courbaril L.) according to DAT (30, 60, 90,120, 150, and 180

DAT) for the nutrient solution

\subsection{Accumulation of Macronutrients}

In general, $H$. courbaril plants tend to accumulate more macronutrients in the leaves, followed by the stem and root, except for $\mathrm{S}$, which tends to be accumulated more in the roots than in the stem, during average periods of development. The plants accumulated $\mathrm{N}$ gradually over the assessment periods. The N content increased relative to the DAT of the leaves, stem, and roots, and the greatest accumulation of this nutrient occurred at 180 DAT, being 20.96, 14.84, and $6.801 \mathrm{~g} \cdot$ plant $^{-1}$, respectively, whereas the smallest accumulation of $\mathrm{N}$ was observed at 30 DAT for the leaves, stem, and roots, being 5.623, 0.843 and $1.431 \mathrm{~g} \cdot$ plant $^{-1}$, respectively (Figure 2a).

The $\mathrm{P}$ content in the leaves, stem, and roots also increased gradually relative to the DAT, and the highest values were observed at 180 DAT, which were $7.86,6.64$, and $3.34 \mathrm{~g} \cdot$ plant $^{-1}$ for the leaves, stem, and roots, respectively. The lowest values were observed at 30 DAT, which were $1.335,0.734 \mathrm{~g} \cdot$ plant $^{-1}$, and $0.557 \mathrm{~g} \cdot$ plant $^{-1}$ for the leaves, stem, and roots, respectively (Figure 2b).

Regarding the potassium content in the leaves, stem, and roots, the highest values were also verified at $180 \mathrm{DAT}$, which were $12.183,6.431$, and $4.239 \mathrm{~g} \cdot$ plant $^{-1}$, respectively. The lowest values were observed at 30 DAT, which were $1.824,1.625$, and $0.916 \mathrm{~g} \cdot$ plant $^{-1}$ also for the leaves, stem, and roots, respectively (Figure 2c).

Calcium was also accumulated linearly in the organs over the development time. The highest contents were verified at 180 DAT for leaves, stem, and roots, which were 11.440, 9.908, and $3.179 \mathrm{~g} \cdot$ plant $^{-1}$, respectively. The lowest values were observed at 30 DAT, which were 2.04, 
0.749, and $0.092 \mathrm{~g} \cdot$ plant $^{-1}$ (Figure 2d).

The Mg content was also higher at 180 DAT for the stem, leaves, and roots at 3.516, 2.3, and $1.443 \mathrm{~g} \cdot$ plant $^{-1}$, respectively. The lowest values were obtained at 30 DAT for the leaves, stem, and roots at $0.436,0,310$, and $0.229 \mathrm{~g} \cdot$ plant $^{-1}$, respectively (Figure 2e).

Differential behavior was verified for only the accumulation of $S$ in the leaves, where the greatest accumulation occurred at 124 DAT $\left(0.539 \mathrm{~g} \cdot\right.$ plant $\left.^{-1}\right)$, whereas the smallest accumulation occurred at 30 DAT $\left(0.111 \mathrm{~g} \cdot\right.$ plant $\left.^{-1}\right)$. For the stem, the highest accumulation was $0.337 \mathrm{~g} \cdot$ plant $^{-1}$ and occurred at 180 DAT and the lowest was $0.072 \mathrm{~g} \cdot$ plant $^{-1}$ at 46 DAT. For the roots, the highest accumulation of $\mathrm{S}$ was $0.319 \mathrm{~g} \cdot$ plant $^{-1}$ at $180 \mathrm{DAT}$ and the lowest $0.040 \mathrm{~g} \cdot$ plant $^{-1}$ at 30 DAT (Figure 2f). 

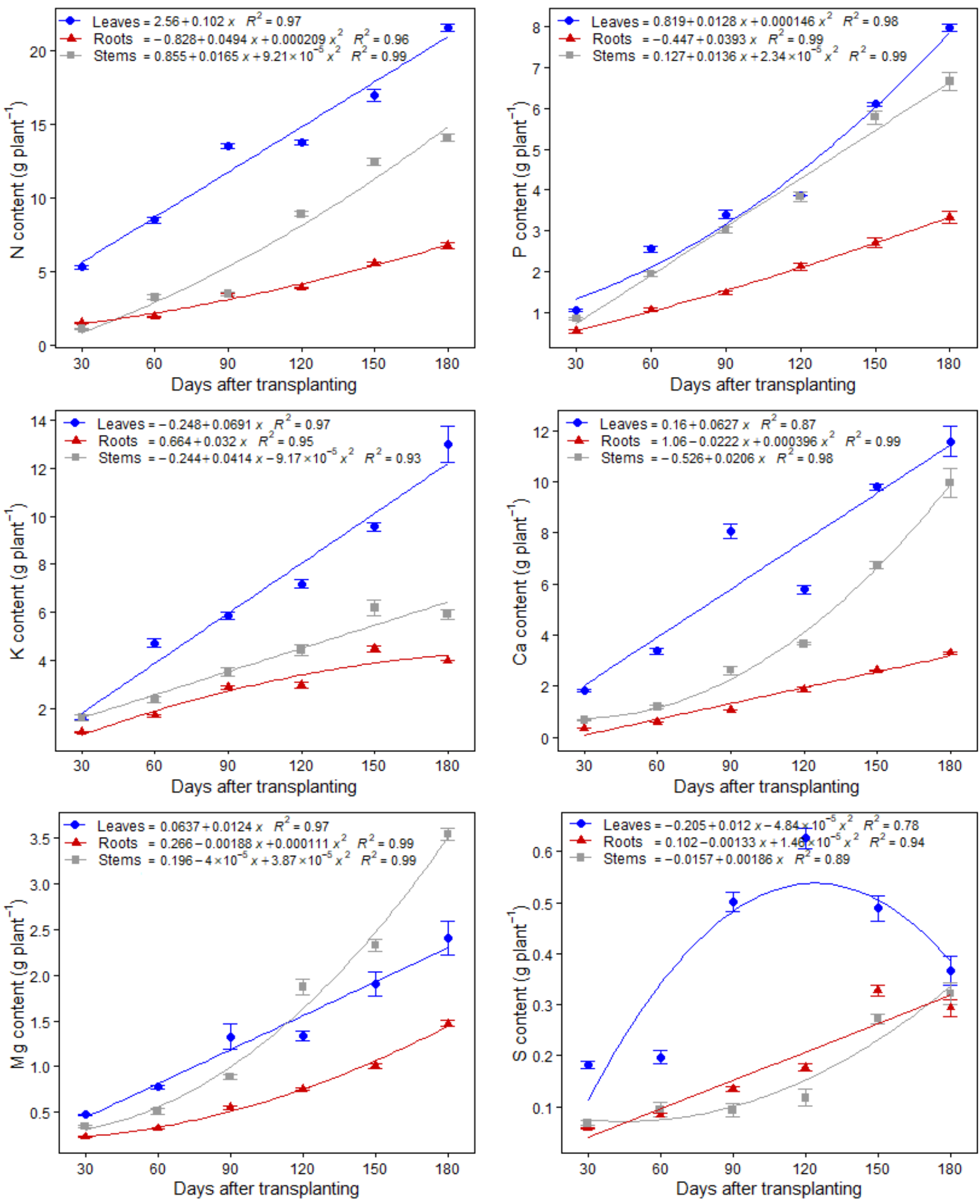

Figure 2. Macronutrient content (N, P, Ca, K, Mg, and S) (g) in the leaves, stems, and roots of jatobá (Hymenaea courbaril L.) seedlings based on DAT (30, 60, 90,120, 150, and 180 DAT) for the nutrient solution 


\section{Ml Macrothink}

The accumulations of macronutrients in the seedlings of $H$. courbaril L. obeyed the following decreasing order at 180 DAT: $\mathrm{N}>\mathrm{Ca}>\mathrm{K}>\mathrm{P}>\mathrm{Mg}>\mathrm{S}$. This same order of monthly accumulation was observed in all evaluation periods, from 30 to 180 DAT (Figure 3).

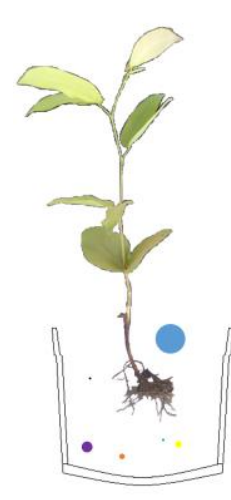

30 DAT

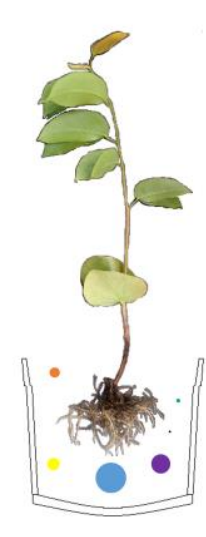

60 DAT

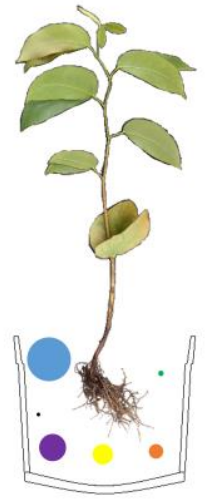

90 DAT

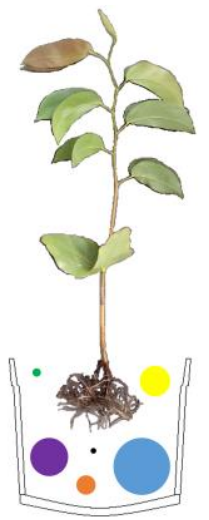

120 DAT

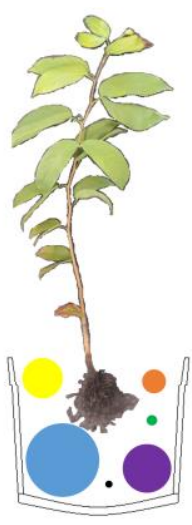

150 DAT

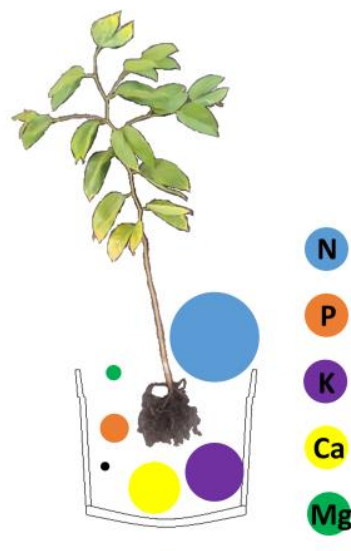

180 DAT

Figure 3. Growth and accumulation of macronutrients (N, P, Ca, K, Mg, and S) (g) in jatobá seedlings (Hymenaea courbaril L.) depending on DAT (30, 60, 90,120, 150, and 180 DAT) for the nutrient solution. The size of the plant is proportional to the accumulation of biomass and the size of the circles is proportional to the total content of each macronutrient $(\mathrm{g})$ observed in the different periods

The behavior of micronutrients in the $H$. courbaril plant was similar to that observed for macronutrients, which tend to accumulate more in the leaves, followed by the stem and root, except for iron, which remained accumulated in the root, in most periods evaluated, but was allocated to the leaves exclusively in the last two evaluation periods (120 and 180 DAT). Zinc was also an exception to this rule, as it was accumulated more in the stem than in the leaves in the last evaluation periods (120 and 180 DAT).

Boron (B) had the highest content at 180 DAT for leaves, stem, and roots at $0.773,0.376$, and $0.205 \mathrm{mg} \cdot$ plant $^{-1}$, respectively. The lowest contents were observed at $30 \mathrm{DAT}$, which were 0.155, 0.092, and $0.048 \cdot \mathrm{mg}^{\prime}$ plant $^{-1}$ for leaves, stem, and roots, respectively (Figure 4a).

The highest copper $(\mathrm{Cu})$ contents were also observed at 180 DAT for leaves, stem, and roots, at $1.288,0.137$, and $0.0463 \mathrm{mg} \cdot$ plant $^{-1}$, respectively. The stem had the lowest $\mathrm{Cu}$ content at 33 DAT (15.40 mg plant $^{-1}$ ), whereas for the leaves and roots, the lowest content was observed at 30 DAT, which were 0.499 and $0.0095 \mathrm{mg} \cdot$ plant $^{-1}$, respectively (Figure 4b).

Fe presented the highest contents at 180 DAT for leaves, roots, and stem, being 4085.56, 2150.50 , and $2742.06 \mathrm{mg}$ plant-1, respectively. The lowest contents of Fe were observed at 30 DAT for the roots and stem, being 876.81 and $203.412 \mathrm{mg} \cdot$ plant $^{-1}$, respectively. For the leaves, the lowest content was verified at 70 DAT $\left(745.85 \mathrm{mg} \cdot\right.$ plant $\left.^{-1}\right)$, as shown in Figure $4 \mathrm{c}$.

Manganese also accumulated more in the leaves, stem, and roots at 180 DAT, which were $5168.49,829.59$, and $255.27 \mathrm{mg} \cdot$ plant $^{-1}$, respectively. The lowest contents observed occurred 
at $30 \mathrm{DAT}$ and were $73.02,163.44$, and $1000.29 \mathrm{mg} \cdot$ plant $^{-1}$ in the roots, stem, and leaves, respectively (Figure $4 \mathrm{~d}$ ).

$\mathrm{Zn}$ had its greatest accumulations observed at 180 DAT in the stem, leaves, and roots at 206.573, 196.364, and $89.225 \mathrm{mg} \cdot$ plant $^{-1}$, respectively. While its smallest accumulations were observed at 30 DAT, being 67.016, 19.958, and $19.070 \mathrm{mg} \cdot$ plant $^{-1}$ for leaves, stem, and roots, respectively (Figure 4e). 

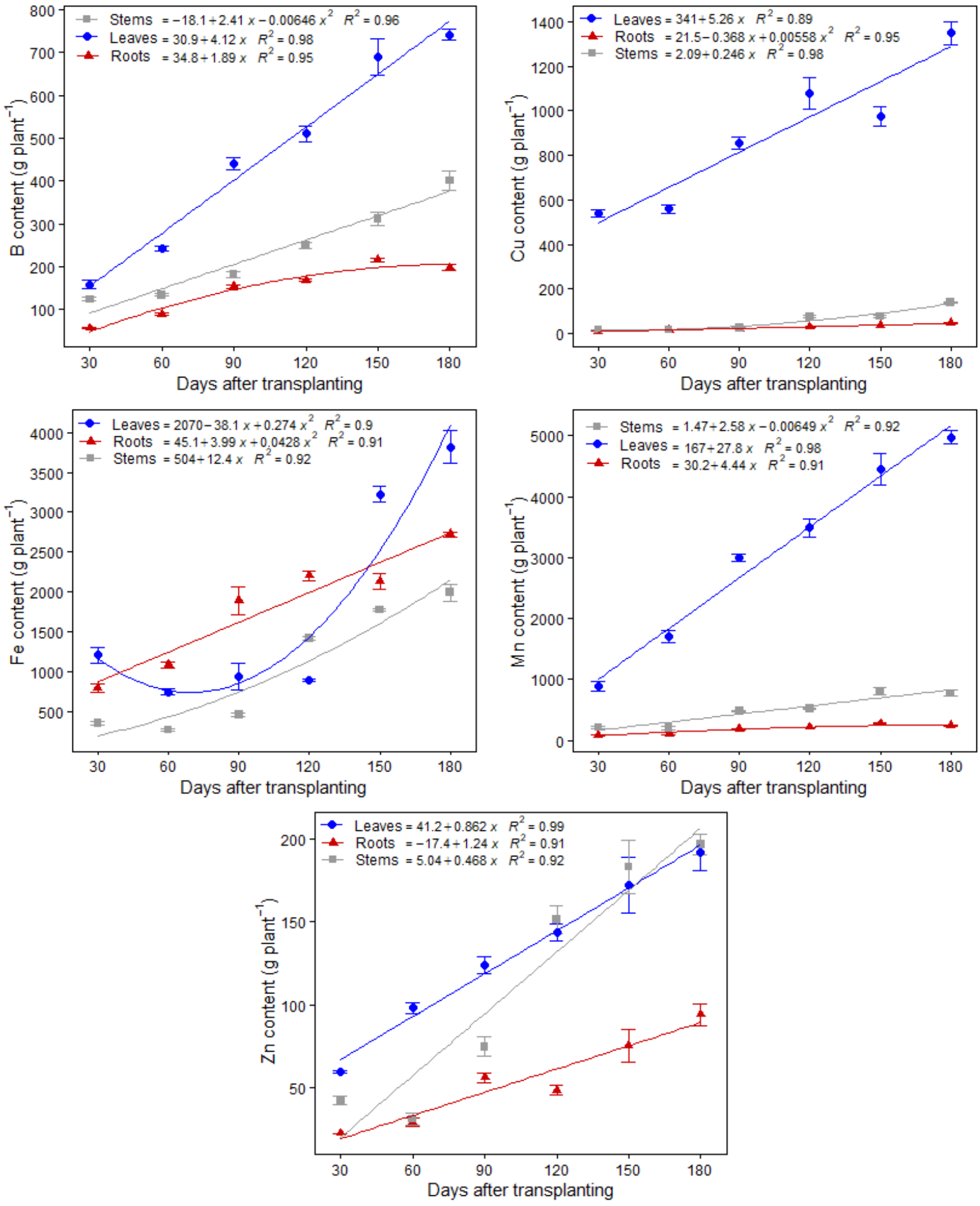

Figure 4. Micronutrient content (B, $\mathrm{Cu}, \mathrm{Fe}, \mathrm{Mn}$, and $\mathrm{Zn})(\mathrm{mg})$ in leaves, stem, and roots of jatobá (Hymenaea courbaril L.) seedlings based on DAT (30, 60, 90,120, 150, and 180 DAT) for the nutrient solution 


\section{Macrothink Institute ${ }^{\mathrm{TM}}$}

The mean micronutrient accumulation in the seedlings of $H$. courbaril obeyed the following decreasing order at 180 DAT: $\mathrm{Fe}>\mathrm{Mn}>\mathrm{Cu}>\mathrm{B}>\mathrm{Zn}$. A similar micronutrient accumulation behavior was observed in all other times of evaluation, except for the 90 DAT where the following decreasing order of accumulation was observed: $\mathrm{Mn}>\mathrm{Fe}>\mathrm{Cu}>\mathrm{B}>\mathrm{Zn}$ (Figure 5).

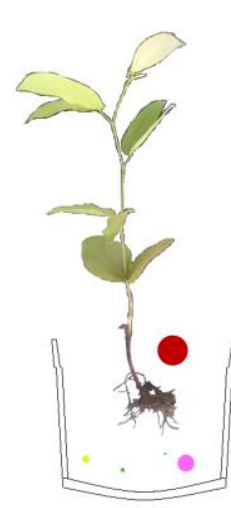

30 DAT

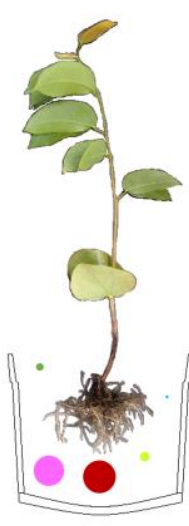

60 DAT

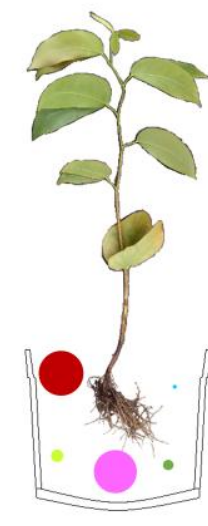

90 DAT

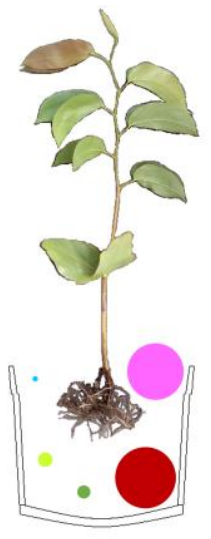

120 DAT

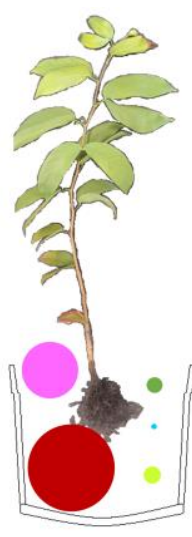

150 DAT

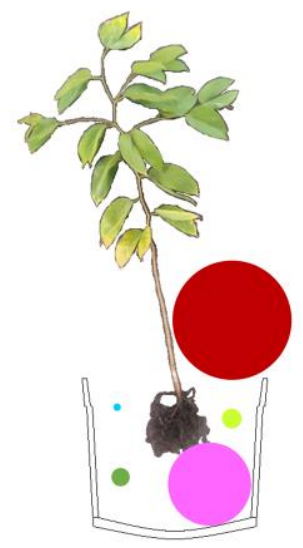

180 DAT

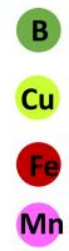
Zn

Figure 5. Growth and accumulation of micronutrients (B, $\mathrm{Cu}, \mathrm{Fe}, \mathrm{Mn}$, and $\mathrm{Zn})(\mathrm{mg})$ in jatobá (Hymenaea courbaril L.) seedlings based on DAT (30, 60, 90,120, 150, and 180 DAT) for the nutrient solution. The size of the plant is proportional to the accumulation of biomass, whereas the size of the circles is proportional to the total content of each micronutrient (mg) observed in the different periods

\subsection{Nutrient Use Efficiency (NUE)}

NUE followed the same pattern throughout the evaluation period. At 30 DAT, the highest use efficiency was observed for $\mathrm{S}$ at $0.018 \mathrm{~g} 2 \cdot \mathrm{g}-1$, followed by $\mathrm{Mg} 0.005 \mathrm{~g}^{2} \cdot \mathrm{g}^{-1}$ (Figure 6a). At 60 DAT, the NUE for S and $\mathrm{Mg}$ were 0.04 and $0.008 \mathrm{~g}^{2} \cdot \mathrm{g}^{-1}$, respectively (Figure 6b). At 90 DAT, the mean NUE estimated for $\mathrm{S}$ was $0.06 \mathrm{~g}^{2} \cdot \mathrm{g}^{-1}$ and the highest sequential results were also determined for $\mathrm{Mg}\left(0.013 \mathrm{~g}^{2} \cdot \mathrm{g}^{-1}\right)$ (Figure 6c).

At 120, 150, and 180 DAT this NUE behavior was repeated, with S showing the highest average efficiency, respectively at $0.06,0.08$, and $0.08 \mathrm{~g}^{2} \cdot \mathrm{g}^{-1}$ and $\mathrm{Mg}$ showing the second-highest efficiency $\left(0.012,0.019\right.$, and $\left.0.016 \mathrm{~g}^{2} \cdot \mathrm{g}^{-1}\right)$ (Figures $\left.6 \mathrm{~d}-\mathrm{e}\right)$.

At the end of the 180 DAT cycle, the following descending order was determined for the NUE values of the macronutrients: $\mathrm{S}>\mathrm{Mg}>\mathrm{P}>\mathrm{Ca}>\mathrm{K}>\mathrm{N}$ (Figure 6f). 


\section{MlMacrothink}

a)

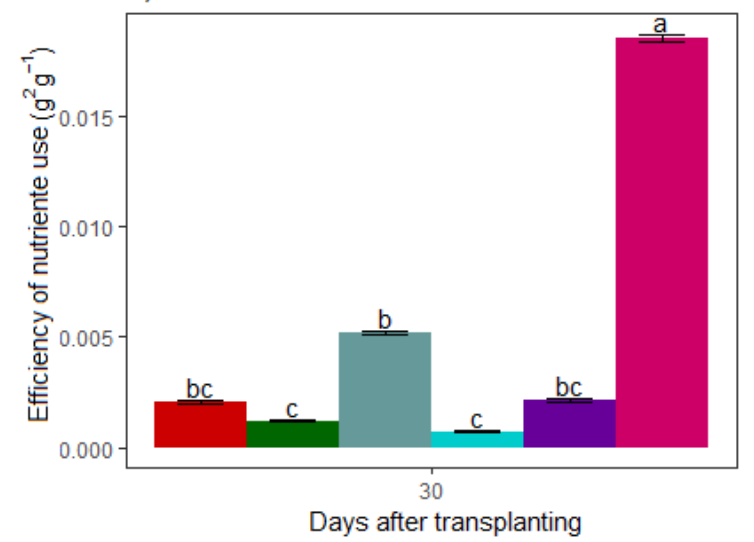

c)

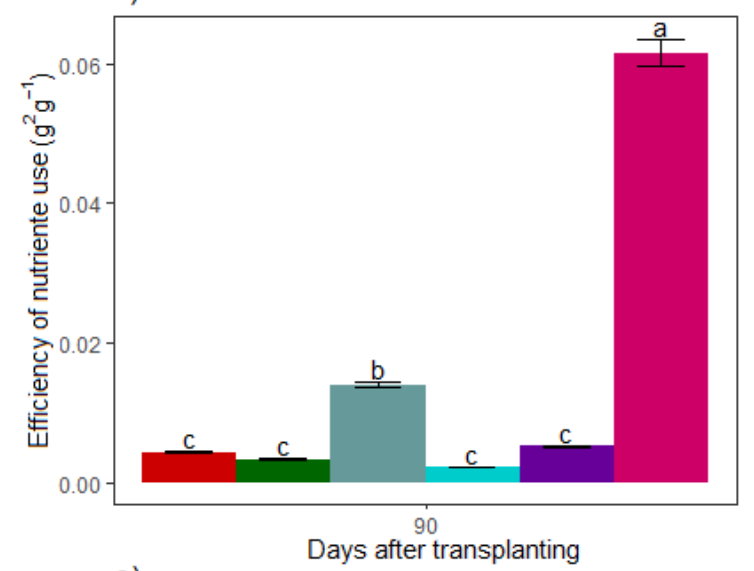

e)

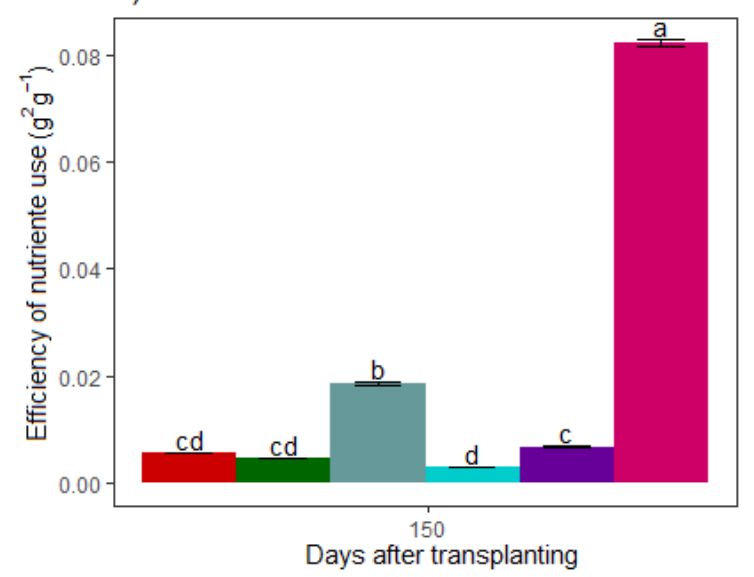

Journal of Agricultural Studies

ISSN 2166-0379

2021, Vol. 9, No. 2
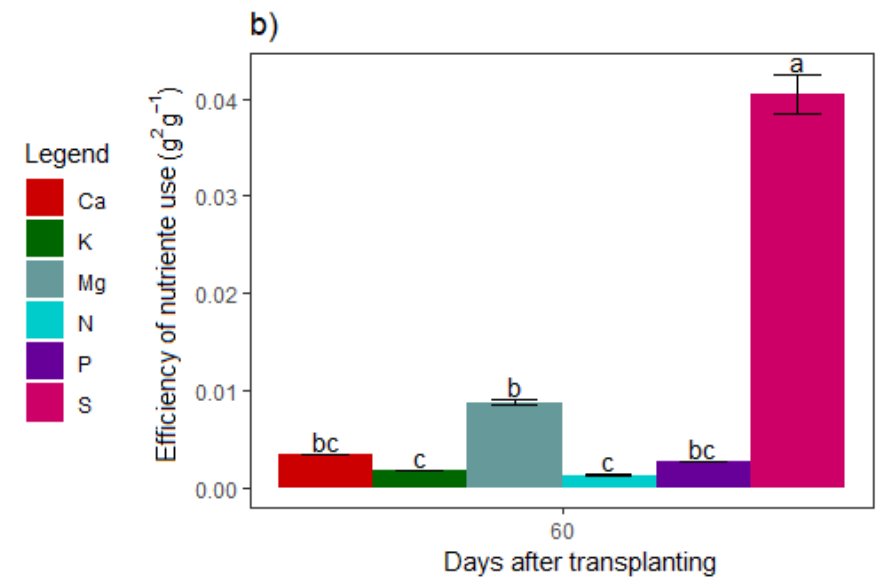

Legend
${ }^{C a}$
${ }^{K}$
$M g$
${ }^{N}$
${ }^{P}$
$S$

d)
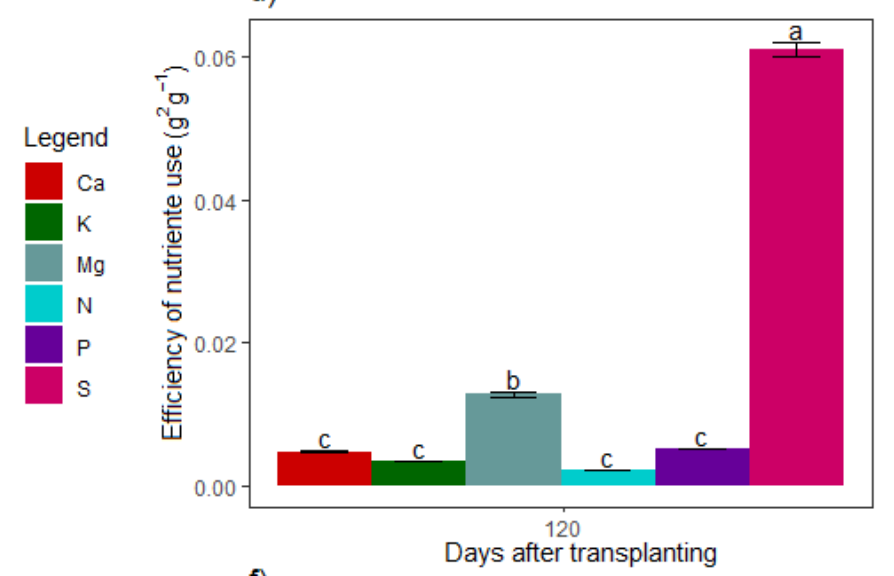

Legend

$\mathrm{Ca}$

$\mathrm{K}$
$\mathrm{Mg}$
$\mathrm{N}$
$\mathrm{P}$
$\mathrm{S}$

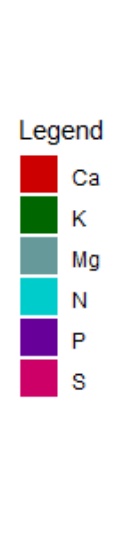

Figure 6: Efficiency of macronutrients (N, P, K, Ca, Mg and S) (g2g-1) in jatobá (Hymenaea courbaril L.) seedlings according to DAT $(30,60,90,120,150$ and 180 DAT) for the nutrient solution

NUE also followed similar a behavior throughout all the periods assessed. $\mathrm{Cu}$ was the most efficient micronutrient used at 30,60,90,120,150, and 180 DAT, with the following average values of NUE: $0.08,0.2,0.45,0.4,0.32$ and $0.41 \mathrm{~g}^{2} \cdot \mathrm{g}^{-1}$, respectively. The lowest average efficiency was observed for Fe at 0.001, 0.004, 0.008, 0.007, 0.012 and $0.010 \mathrm{~g}^{2} \cdot \mathrm{g}^{-1}$ and for $\mathrm{Mn}$ at $0.006,0.011,0.015,0.016,0.023$ and $0.023 \mathrm{~g}^{2} \cdot \mathrm{g}^{-1}$, at 30, 60, 90, 120, 150 and 180 


\section{Macrothink}

Journal of Agricultural Studies

ISSN 2166-0379

2021, Vol. 9, No. 2

DAT, respectively (Figures $7 \mathrm{a}-\mathrm{f}$ ).

For micronutrients at the end of the 180 DAT cycle, the following descending order was checked for the NUE values: $\mathrm{Cu}>\mathrm{Zn}>\mathrm{B}>\mathrm{Mn}>\mathrm{Fe}$.

a)

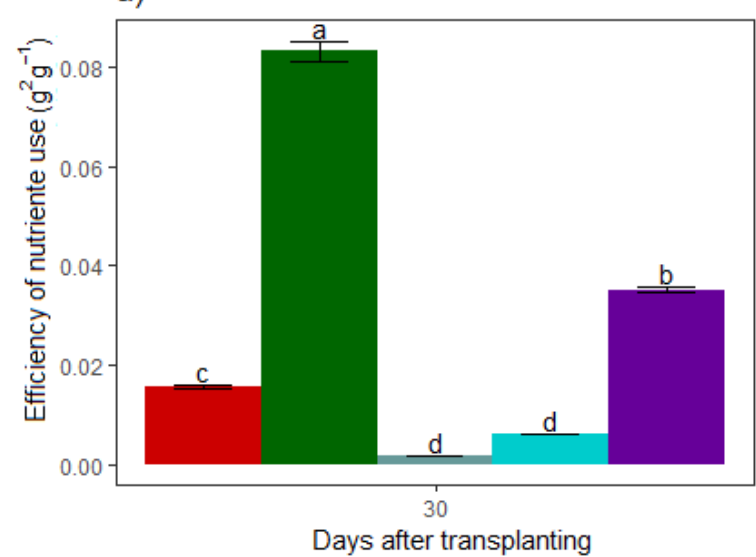

c)

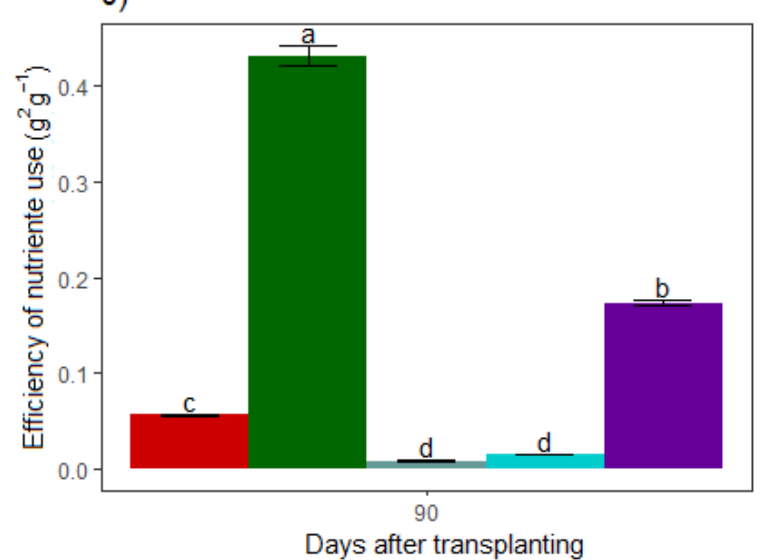

e)

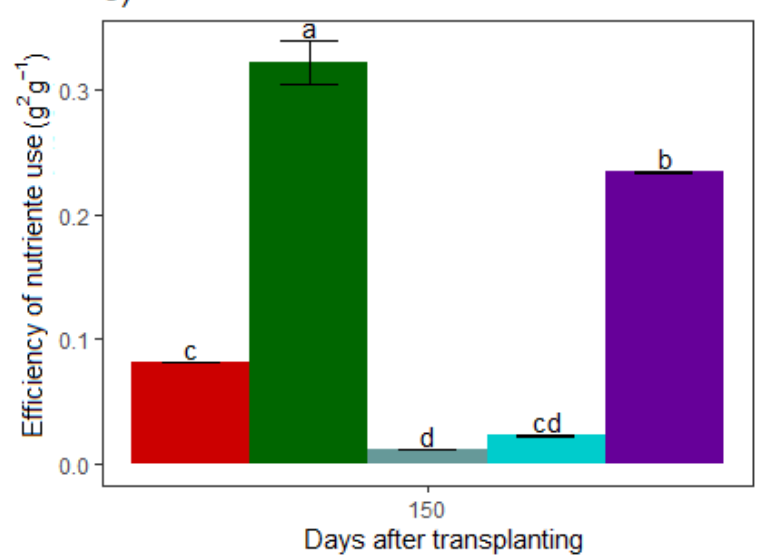

b)

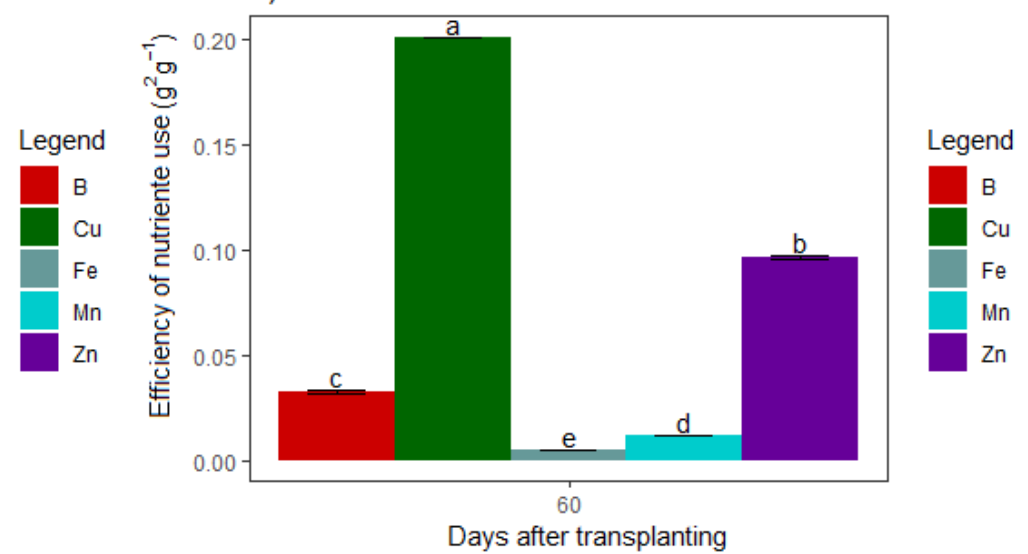

d)
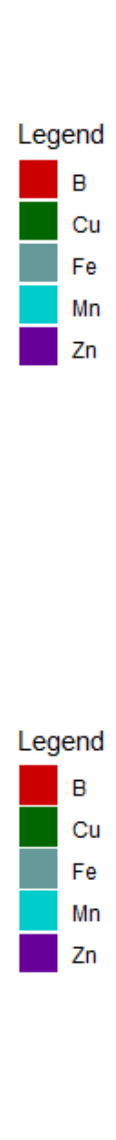

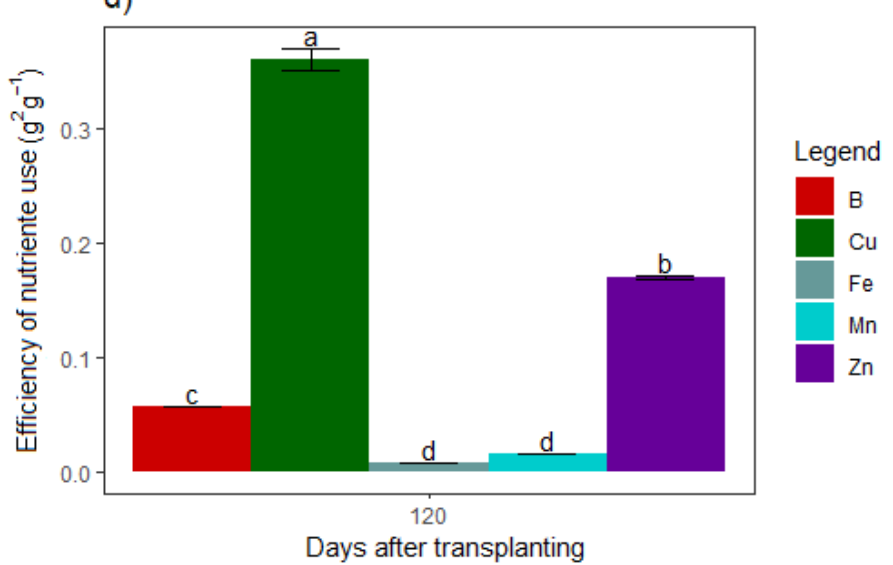

f)

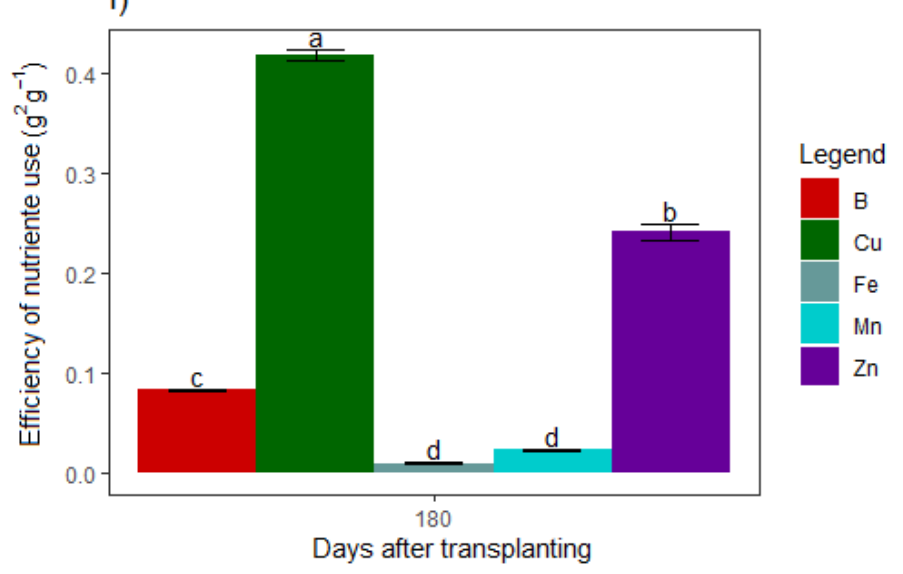

Figure 7. Efficiency of micronutrient (B, Cu, Fe, Mn, and Zn) (g2g-1) use in jatobá (Hymenaea courbaril L.) seedlings based on DAT (30, 60, 90,120, 150, and 180 DAT) for the nutrient solution

The absorption efficiency of macronutrients followed a similar pattern throughout all 
evaluated periods, except for the cycle at 180 DAT, when the absorption of Ca exceeded that of $\mathrm{K}$. Therefore, in general, the highest mean absorption was observed for $\mathrm{N}$ at 30,60,90, 120, 150, and 180 DAT, with the following mean values: 29261.10, 40259.43, 32898.93, $40849.42,35487.69$, and $42565.92 \mathrm{mg} \cdot \mathrm{g}^{-1}$, respectively. However, the lowest means for NAE were observed for S $(1293.182,1221.65,1414.01,1311.72$, and 1137.90 at 60, at 90, 120, 150, and 180 DAT, respectively) (Figures 8a-f).

At the end of the 180 DAT crop cycle, the following decreasing order was determined for the efficiency of macronutrient absorption in jatobá seedlings: $\mathrm{N}>\mathrm{K}>\mathrm{P}>\mathrm{Ca}>\mathrm{Mg}>\mathrm{S}$.

a)

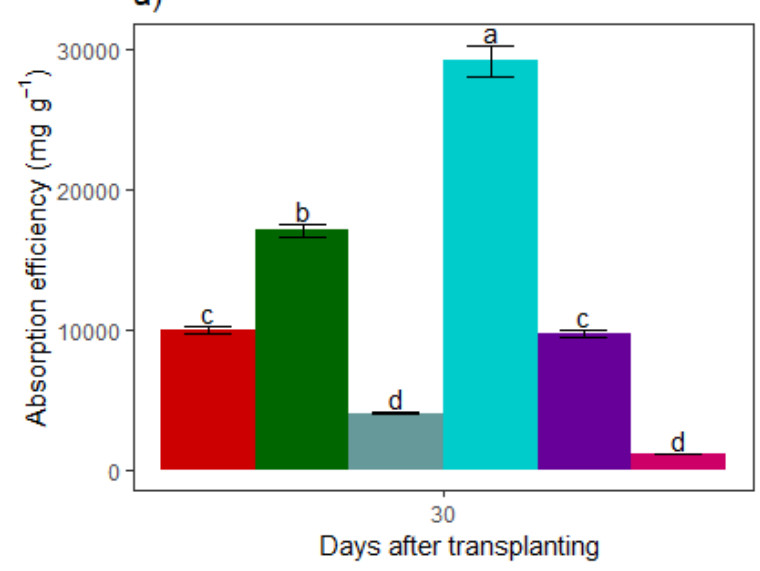

c)

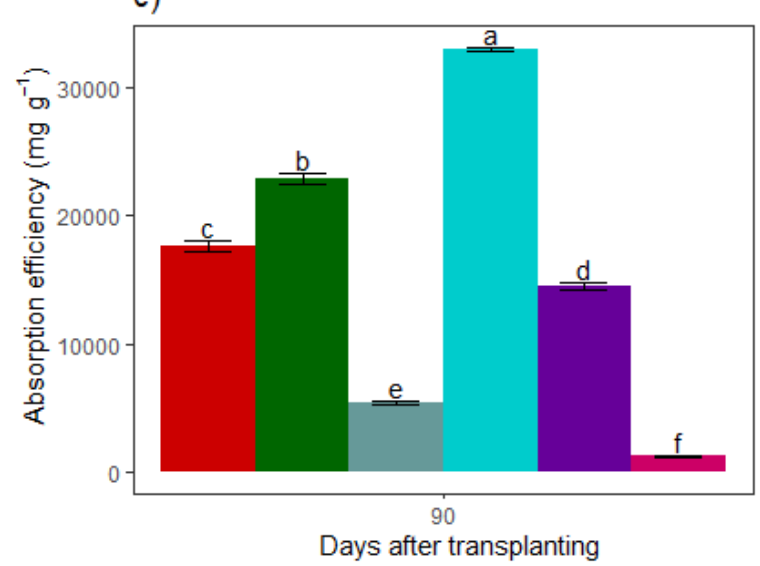

e)

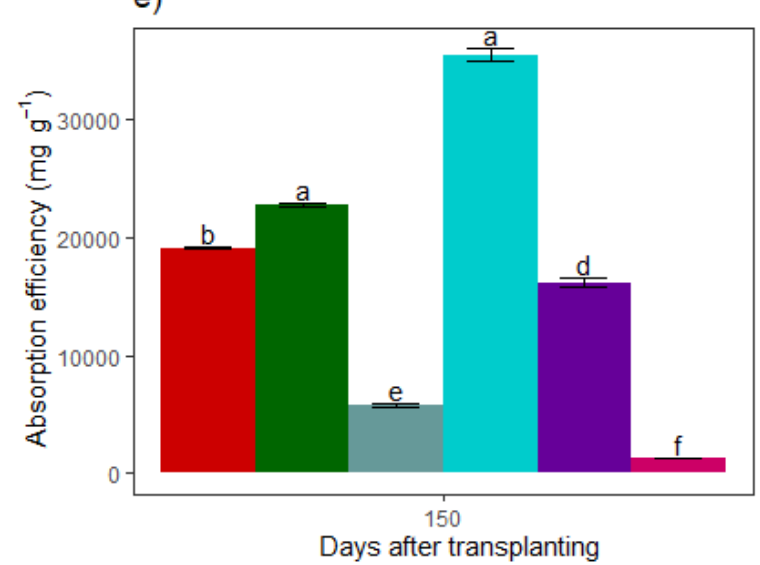

b)

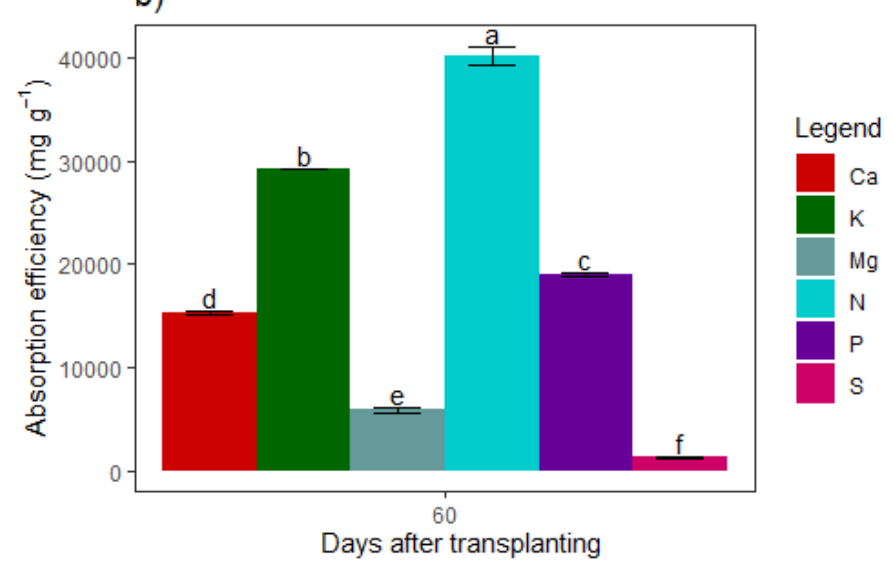

d)

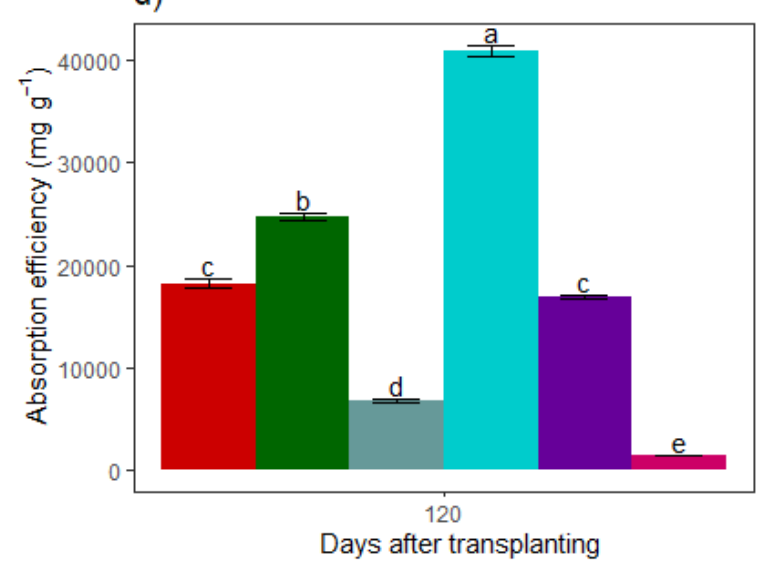

f)

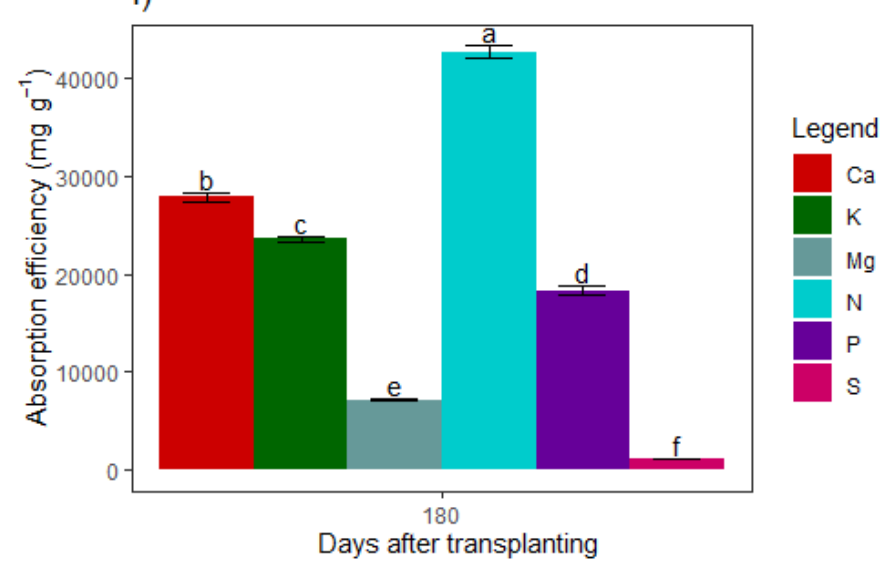




\section{Macrothink}

Figure 8. Macronutrient absorption efficiency (N, P, Ca, K, Mg, and S) $\left(\mathrm{mg} \cdot \mathrm{g}^{-1}\right)$ in jatobá (Hymenaea courbaril L.) seedlings depending on DAT (30, 60, 90, 120, 150, and 180 DAT) for the nutrient solution

Concerning the NEA of micronutrients, the pattern was also similar throughout the seedling development. The highest mean NEA was determined for Fe at 30, 60, 90, 120, 150, and 180 DAT with the following mean values: $11453.14,11360.48,8843.06,10941.81,9946.60$, and $11220.97 \mathrm{mg} \cdot \mathrm{g}^{-1}$, respectively. The lowest mean efficiency was determined for $\mathrm{Cu}$ at 751.32 , 768.58, 520.81, 720.47, 1024.97 and $843.94 \mathrm{~g}^{2} \cdot \mathrm{g}^{-1}$ and for $\mathrm{Zn}$ at 1773.73, 1603.05, 1292.38, $1525.12,1381.88$ and $1469.79 \mathrm{~g}^{2} \cdot \mathrm{g}^{-1}$ at cycles of $30,60,90,120,150$ and 180 DAT, respectively (Figure 9a-f).

At the end of the 180 DAT crop cycle, the following decreasing order was determined for the micronutrient absorption efficiency in jatobá seedlings: $\mathrm{Fe}>\mathrm{Mn}>\mathrm{B}>\mathrm{Zn}>\mathrm{Cu}$. 


\section{MlMacrothink}

a)

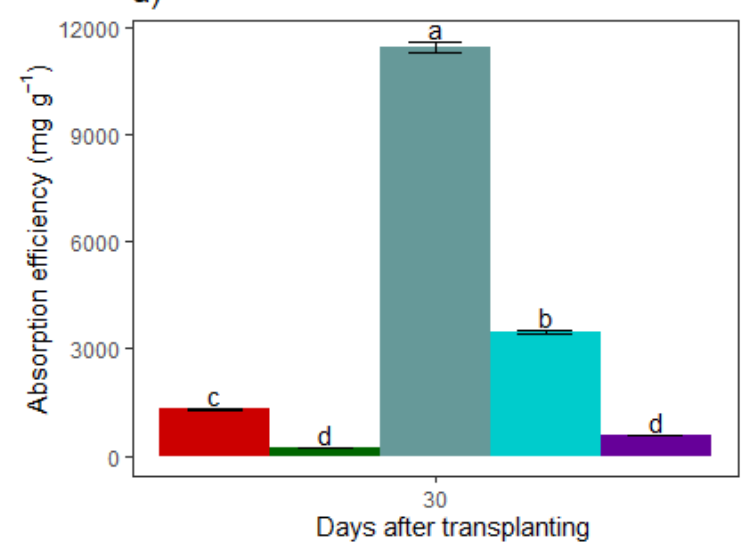

c)

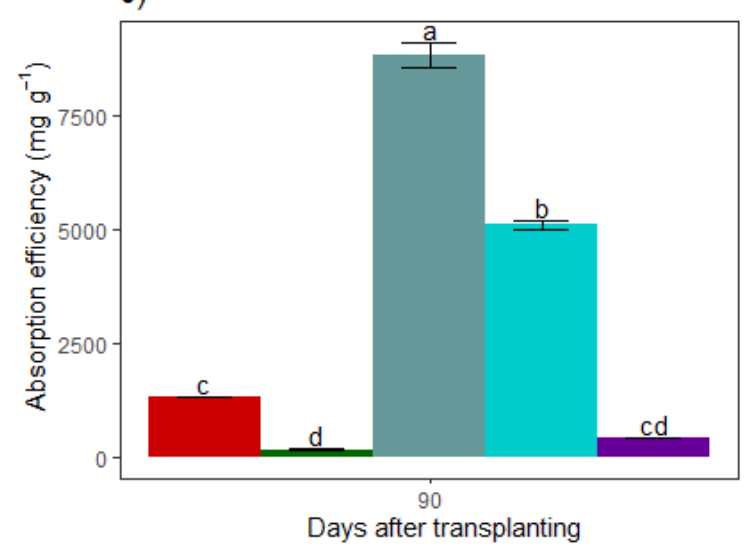

e)

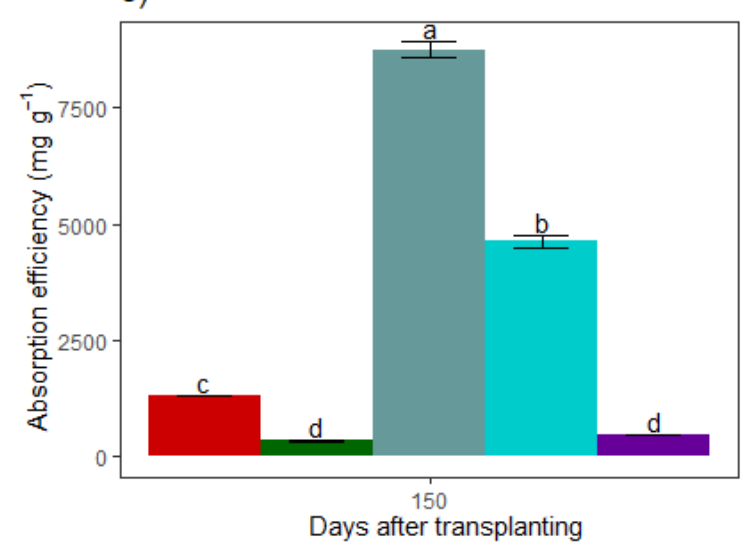

Journal of Agricultural Studies

ISSN 2166-0379

2021, Vol. 9, No. 2
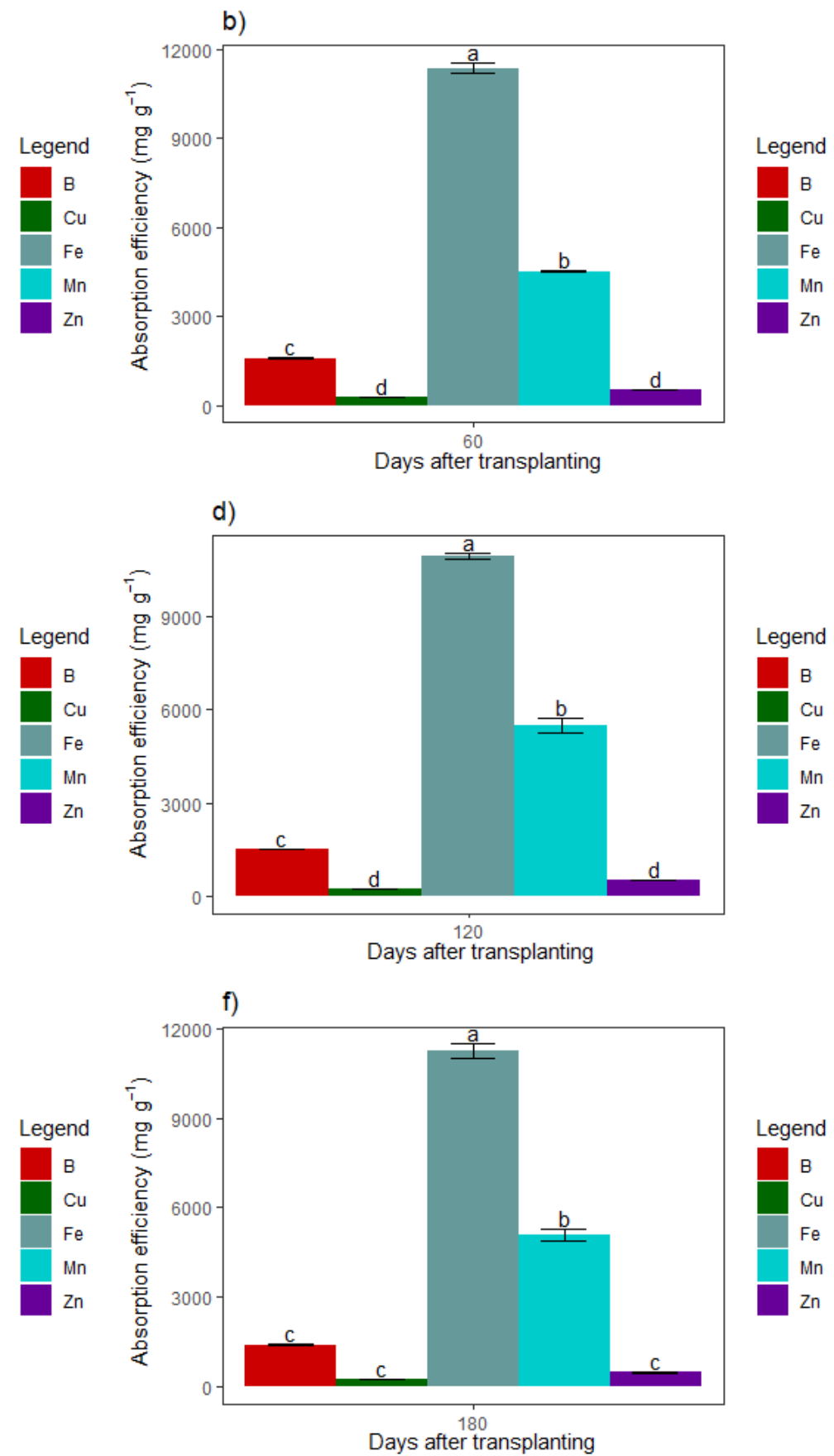

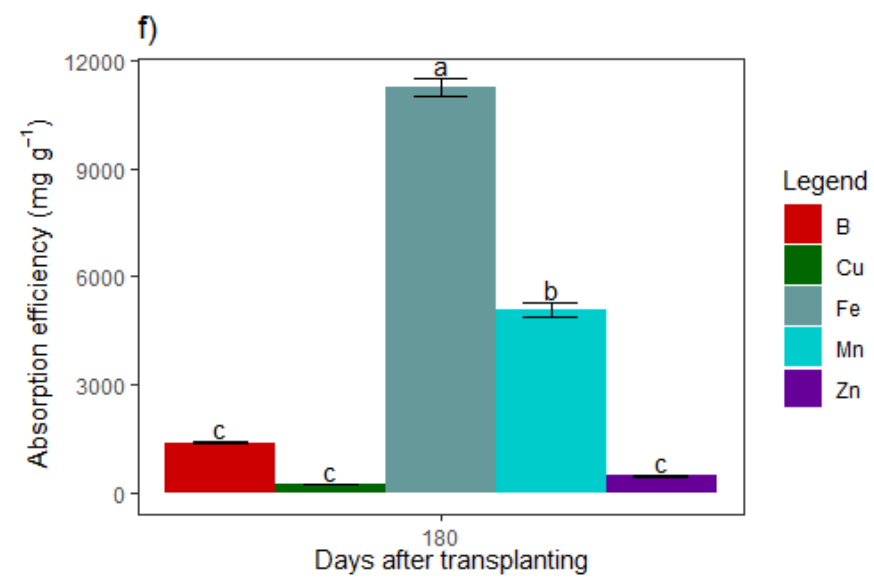

Figure 9. Micronutrient absorption efficiency (B, Cu, Fe, Mn, and $\mathrm{Zn})\left(\mathrm{mg} \cdot \mathrm{g}^{-1}\right)$ in jatobá (Hymenaea courbaril L.) seedlings depending on DAT (30, 60, 90, 120, 150, and 180 DAT) for the nutrient solution

The efficiency pattern in the translocation of macronutrients varied throughout the development of $H$. courbaril plants, and at 30 DAT the highest values of NTE were observed for $\mathrm{Ca}$ with an efficiency of $63.04 \%$ while the other macronutrients exhibited lower efficiency as $\mathrm{N}, \mathrm{Mg}, \mathrm{K}, \mathrm{P}$, and S had NTEs of 48.04\%, 52.42\%, 52.64, 53.00\%, and 53.34\%, respectively (Figure 10a). At 60 DAT, the largest NTEs were verified for N and Ca with efficiencies of $58.21 \%$ and $57.59 \%$. The other macronutrients exhibited lower efficiencies 


\section{Macrothink}

because $\mathrm{Mg}, \mathrm{K}, \mathrm{P}$, and $\mathrm{S}$ had NTEs of $45.83 \%, 52.70 \%, 51.50$, and 48.83\%, respectively (Figure 10b).

At 90 DAT, no difference in translocation efficiency was observed between the macronutrients (Figure 10c). At 120 DAT, the highest translocation efficiencies were exhibited by $\mathrm{S}$ and $\mathrm{N}$ at $56.91 \%$ and $56.59 \%$, respectively. The lowest value of TN was exhibited by $\mathrm{P}$ at $47.11 \%$ (Figure 10d). At 150 DAT, the largest NTE was observed for Ca with an efficiency of $59.49 \%$ and the lowest was observed for $\mathrm{S}$ at $41.49 \%$ (Figure 10e).

At the end of the 180 DAT cycle, high translocation efficiencies were observed for $\mathrm{Mg}, \mathrm{Ca}, \mathrm{N}$, $\mathrm{P}, \mathrm{K}$, respectively at $59.66 \%, 56.66 \%, 55.42 \%, 55.30 \%$, and $53.49 \%$, respectively, and the lowest efficiency for $\mathrm{S}$ was at $39.92 \%$ (Figure 10f), thus obeying the following descending order: $\mathrm{Mg}>\mathrm{Ca}>\mathrm{N}>\mathrm{P}>\mathrm{K}>\mathrm{S}$. 


\section{Macrothink $\Lambda$ Institutem}

a)

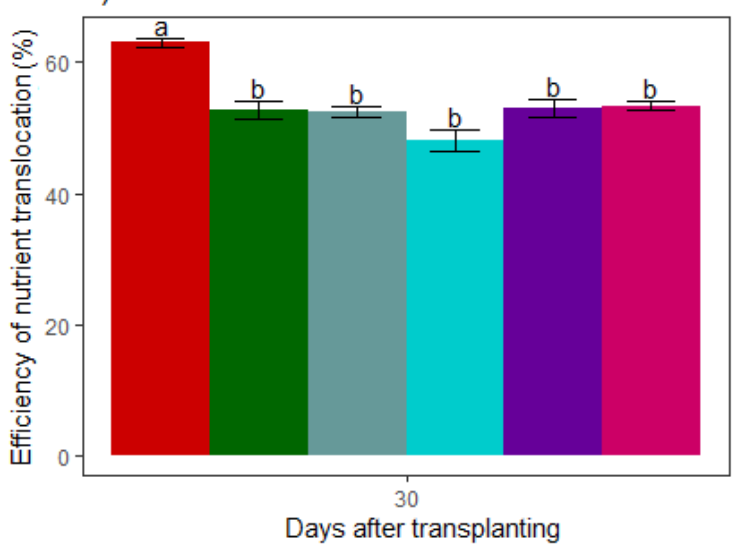

c)

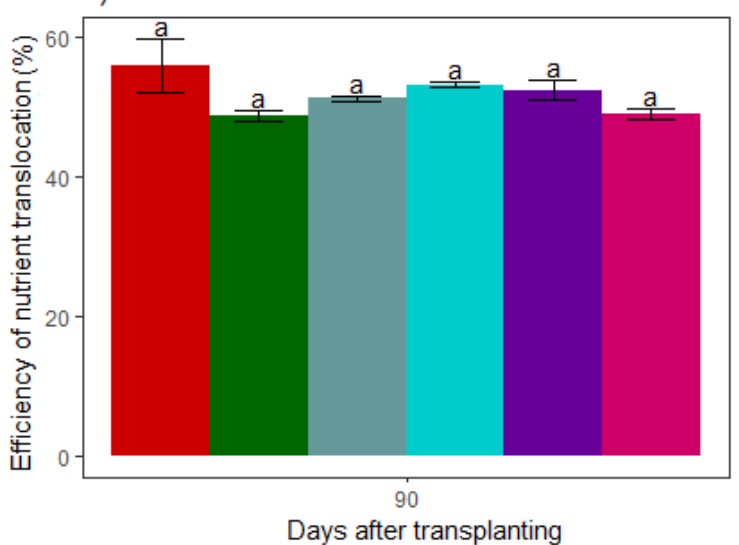

e)

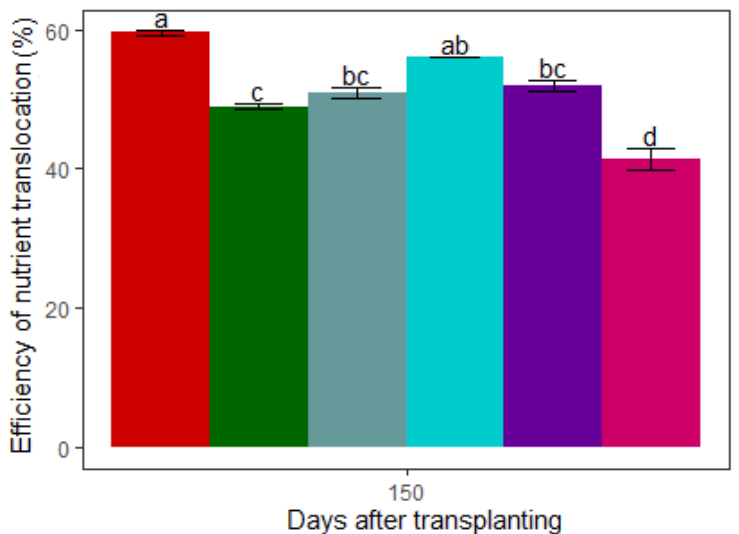

Journal of Agricultural Studies

ISSN 2166-0379 2021, Vol. 9, No. 2
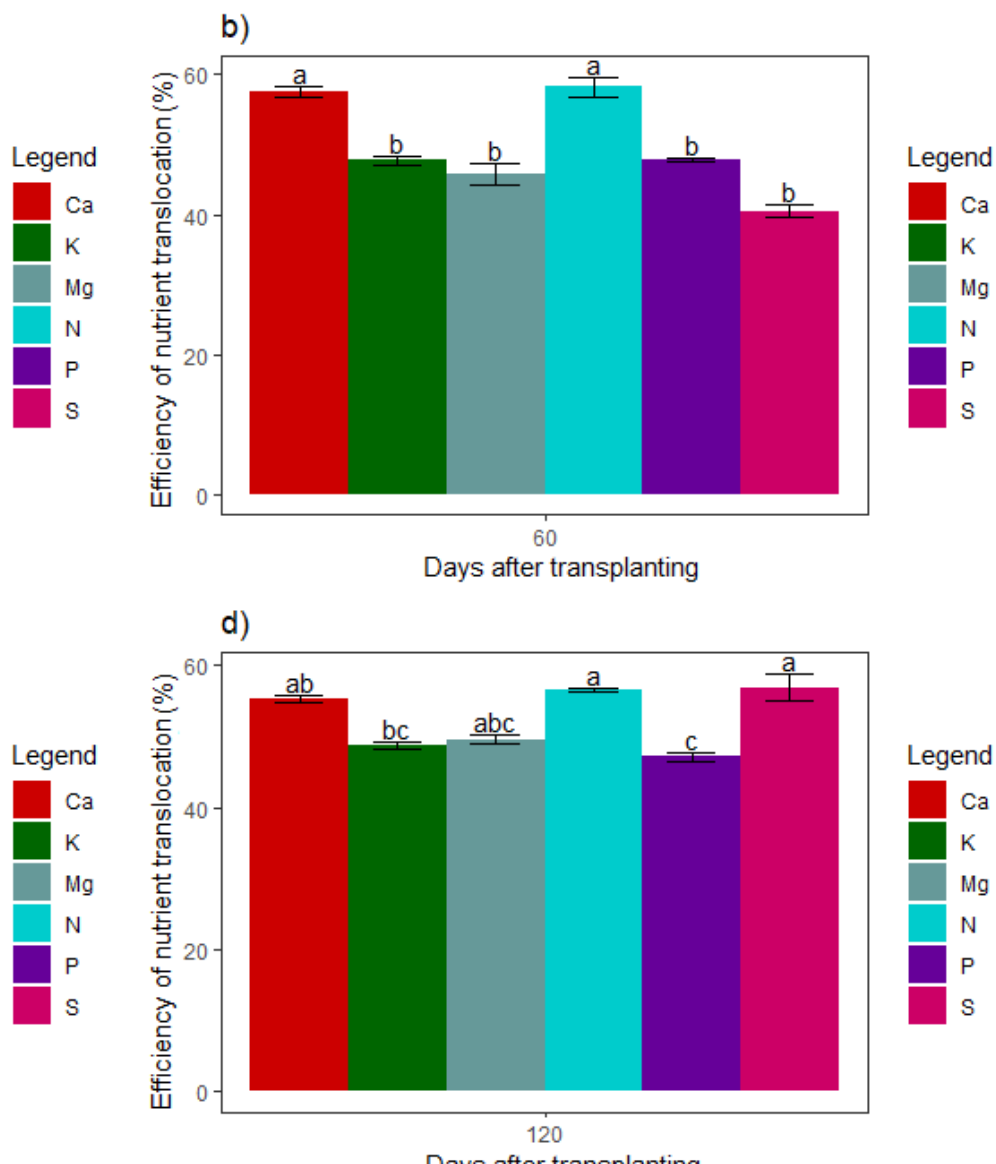

d)
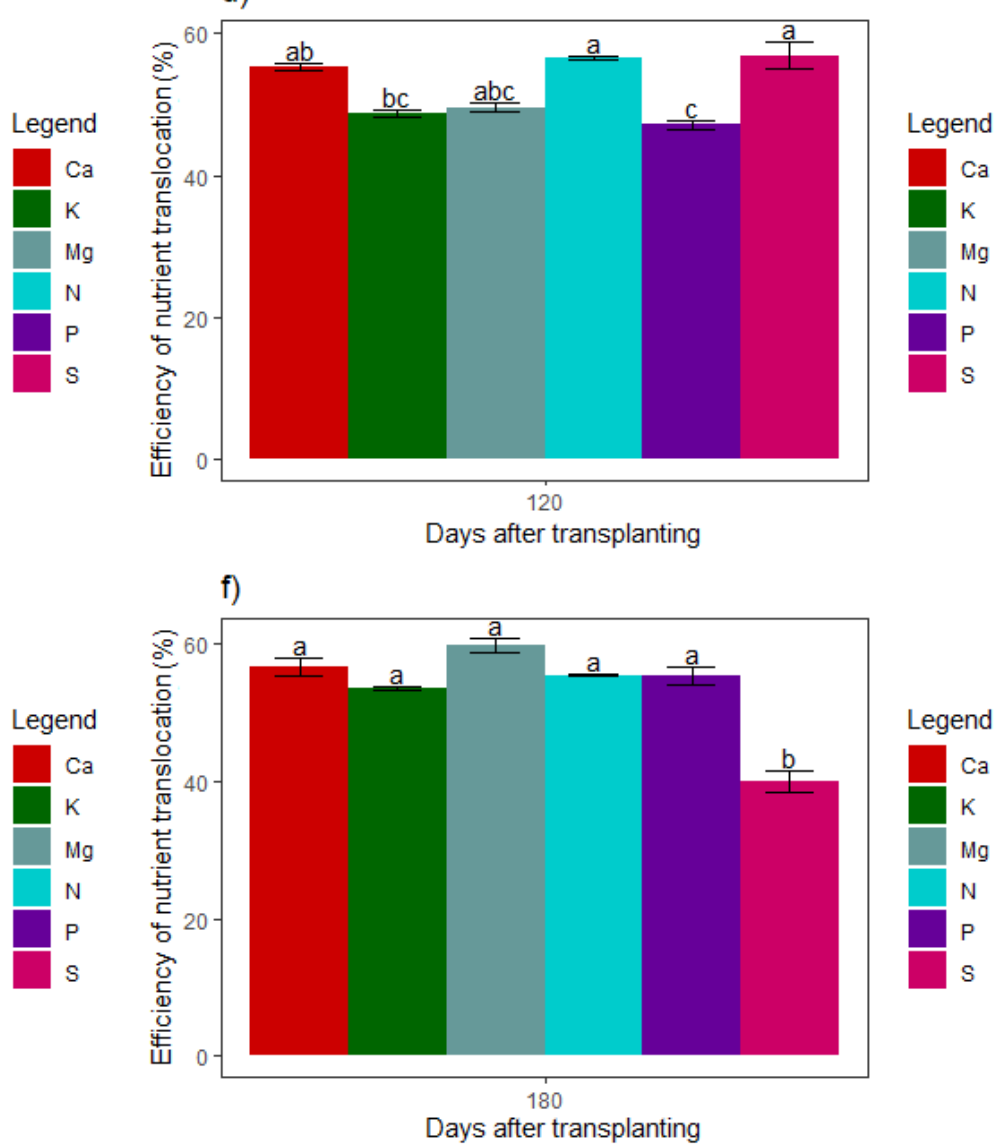

Figure 10. Efficiency of macronutrient translocation (N, P, Ca, K, Mg, and S) (\%) in jatobá (Hymenaea courbaril L.) seedlings depending on DAT (30, 60, 90, 120, 150, and 180 DAT) for the nutrient solution

NTE patterns for micronutrients varied subtly over the evaluation period. At 30 DAT, the highest NTE was observed for Mn at $72.03 \%$, with the other macronutrients exhibiting lower efficiencies, as $\mathrm{Zn}, \mathrm{B}, \mathrm{Cu}$, and Fe had TNAs of 50.91\%, 55.79\%, 48.42, and 45.39\%, respectively (Figure 11a). At 60 DAT, the highest NTE values were also observed for Mn $(75.57 \%)$ and the lowest for Fe (21.63\%) (Figure 11b). 


\section{Macrothink Institute ${ }^{\mathrm{TM}}$}

At 90 DAT, the behavior observed at 60 DAT was repeated, where the Mn exhibited the largest NTE (69.75\%) and Fe the smallest (18.15\%) (Figure 11c). At 120 DAT, although Fe exhibited the smallest NTE again(21.18\%), the other micronutrients, $\mathrm{Zn}, \mathrm{Mn}, \mathrm{B}$, and $\mathrm{Cu}$, exhibited higher values at 61.39\%, 57.36\%, 51.59\%, and 44.35\%, respectively (Figure 11d).

At 150 DAT, the Mn exhibited the highest NTE value (76.18\%) and the lowest efficiency continued to be observed for Fe (42.16\%) (Figure 11e), a pattern that was also repeated at 180 DAT, with the NTEs for Mn and Fe at $79.19 \%$ and 33.65\%, respectively (Figure 11f).

At the end of the 180 DAT cycle, the following descending order for micronutrient translocation efficiency was determined: $\mathrm{Mn}>\mathrm{B}>\mathrm{Zn}>\mathrm{Cu}>\mathrm{Fe}$.

a)

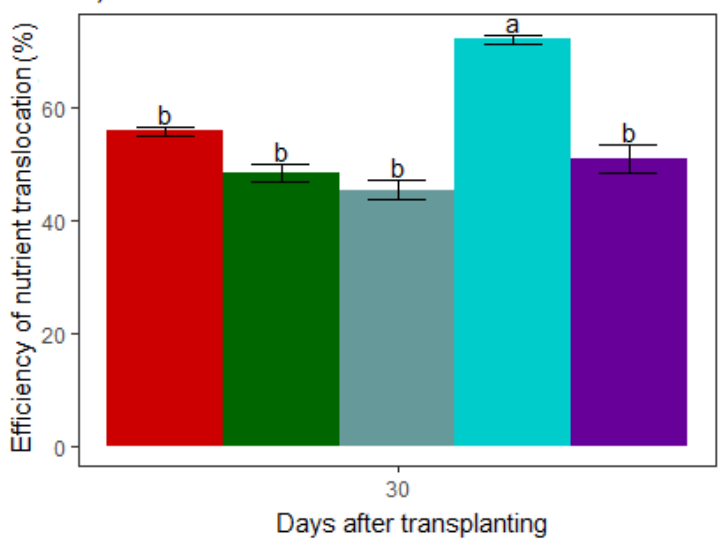

c)

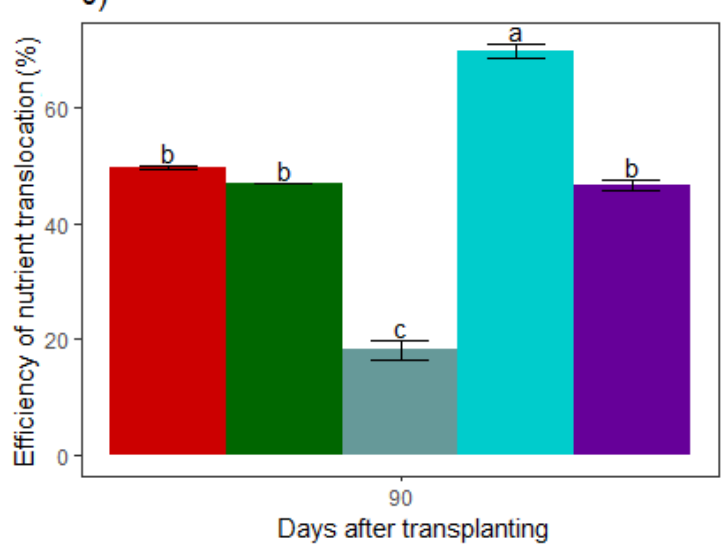

e)

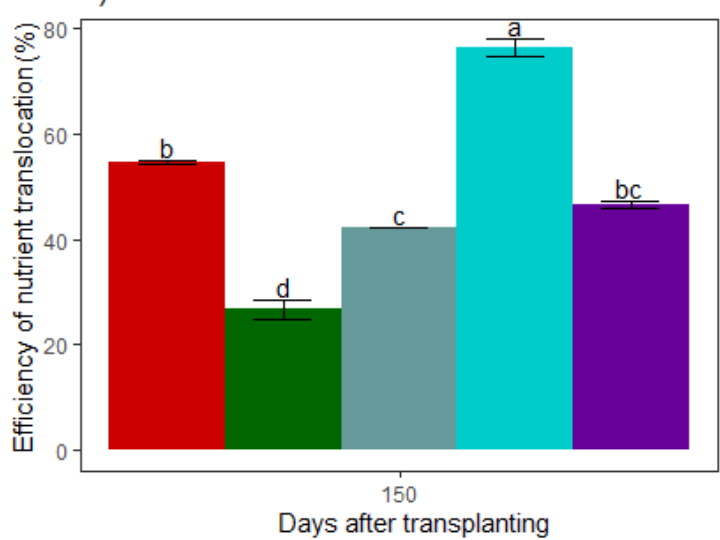

b)

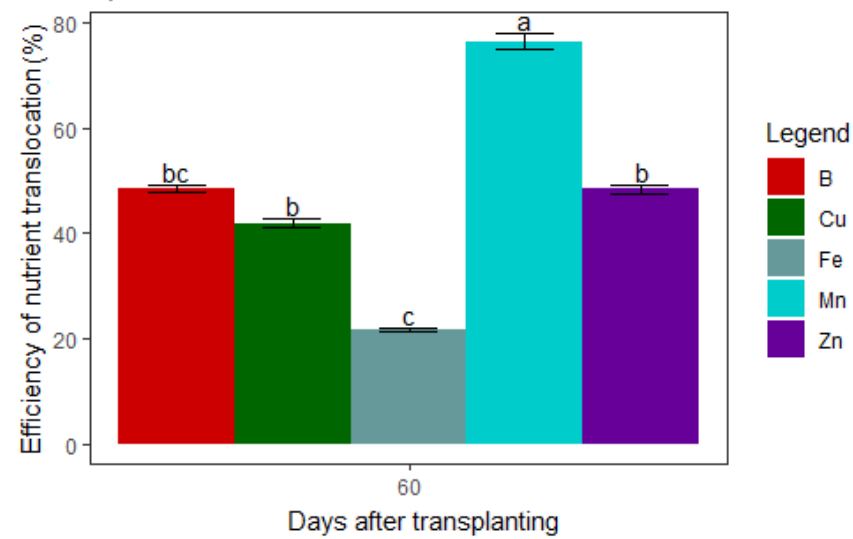

d)
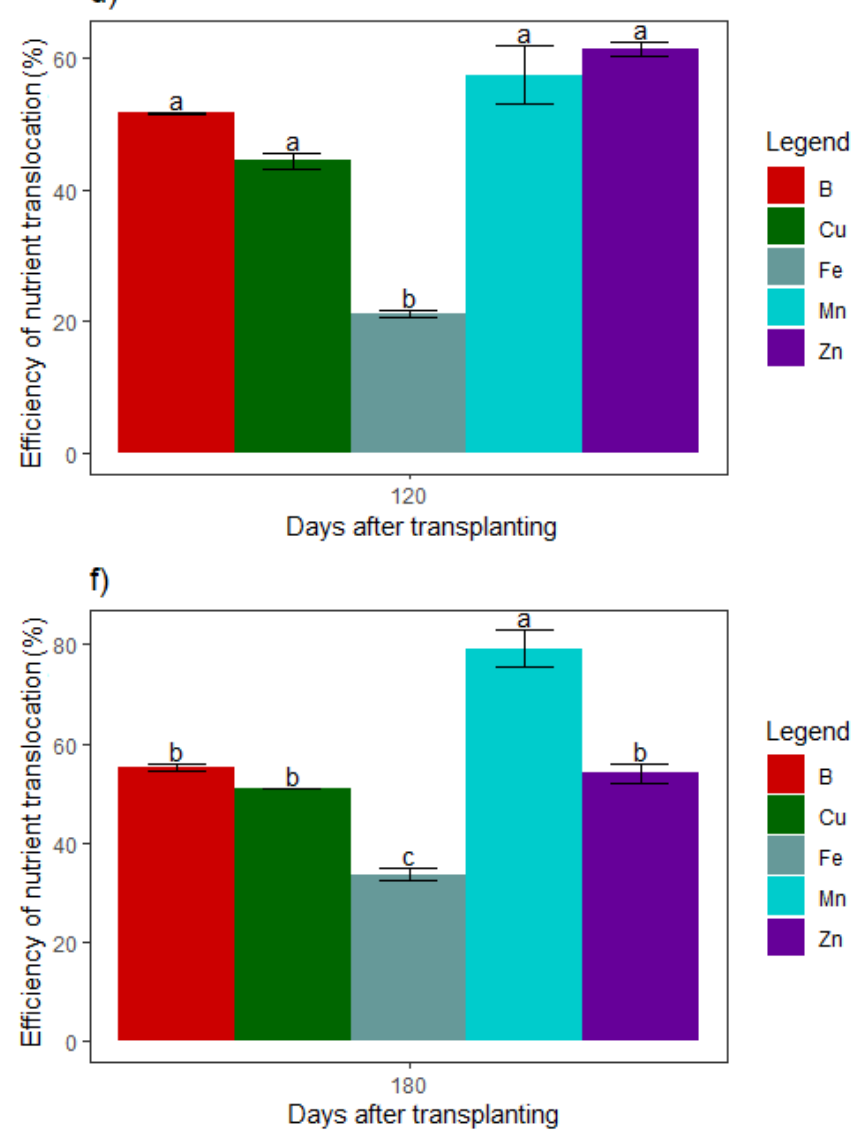


\section{Macrothink}

Figure 11. Translocation of micronutrients $(\mathrm{B}, \mathrm{Cu}, \mathrm{Fe}, \mathrm{Mn}$, and $\mathrm{Zn})(\%)$ in jatobá seedlings (Hymenaea courbaril L.) based on DAT (30, 60, 90, 120, 150, and 180 DAT) for the nutrient solution.

\subsection{Correlations between macro, micronutrients, and biometric growth data}

The $\mathrm{N}$ content in the seedlings of $H$. courbaril was robust and positively correlated to the $\mathrm{Mg}$ $(\mathrm{r}=0.47, \mathrm{p}=0.030)$ and $\mathrm{Fe}(\mathrm{r}=0.41, \mathrm{p}=0.027)$ contents. A robust positive correlation between the contents of $\mathrm{K}$ and $\mathrm{P}$ content $(\mathrm{r}=0.70, \mathrm{p}=0.007), \mathrm{Zn}$ and $\mathrm{Cu}(\mathrm{r}=0.67, \mathrm{p}=0.009)$, and $\mathrm{Mn}$ and $\mathrm{Ca}(\mathrm{r}=0.83, \mathrm{p}=0.004)$, as well as $\mathrm{S}(\mathrm{r}=0.67, \mathrm{p}=0.011)$, was also observed. Strongly negative correlations were determined between $\mathrm{Mn}$ and $\mathrm{Cu}$ contents $(\mathrm{r}=-0.77, \mathrm{p}=$ $0.001)$ and between $\mathrm{S}$ and $\mathrm{Ca}(\mathrm{r}=-0.90, \mathrm{p}=0.000)$ in the seedlings (Figure 12).

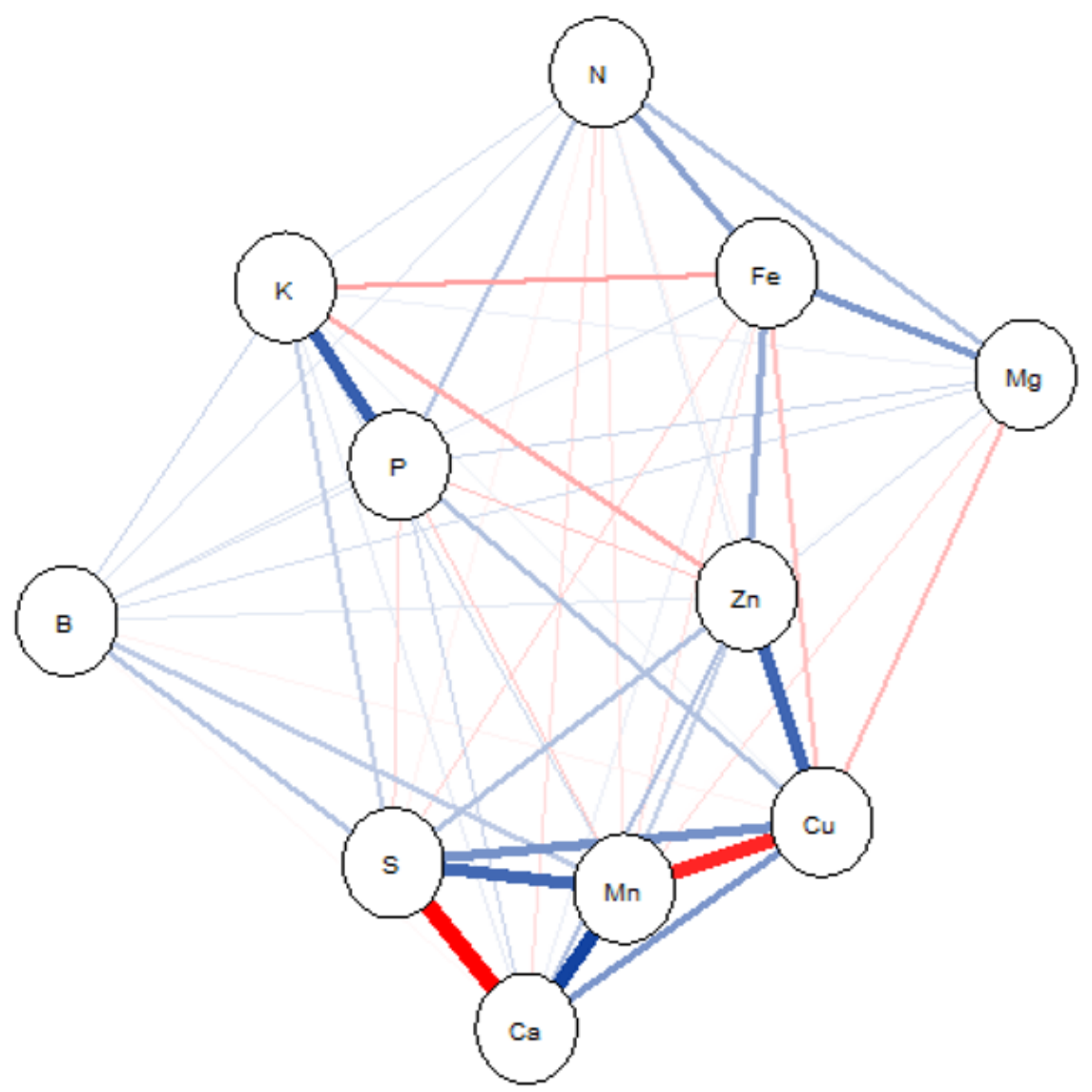

Figure 12. Correlation network between total macro and micronutrient contents, considering the values for leaves, stems, and roots of jatobá (Hymenaea courbaril L.) seedlings at the end of the 180 DAT crop cycle in nutrient solution. Red and green lines represent negative and positive correlations, respectively. The line thickness is proportional to the correlation force

When the macro and micronutrient contents were correlated with the biometric variables, these growth variables were strongly and positively correlated with the $\mathrm{P}, \mathrm{Ca}$, and $\mathrm{Mg}$ contents (Figure 13a). The root length $(\mathrm{r}=0.95, \mathrm{p}=0.003)$, stem diameter $(\mathrm{r}=0.92, \mathrm{p}=$ $0.009)$, total dry mass $(\mathrm{r}=0.89, \mathrm{p}=0.018)$, number of nodes $(\mathrm{r}=0.87, \mathrm{p}=0.026)$, stem length $(r=0.89, p=0.017)$ and number of leaves $(r=0.88, p=0.020)$ increased as the $P$ 


\section{MInstitute ${ }_{\text {Mnk }}^{\text {Macrothin }}$}

Journal of Agricultural Studies

ISSN 2166-0379

2021, Vol. 9, No. 2

content increased (Figure 13b). The root length $(r=0.87, p=0.017)$, stem diameter $(r=0.91$, $\mathrm{p}=0.009)$, total dry mass $(\mathrm{r}=0.87, \mathrm{p}=0.025)$, stem length $(\mathrm{r}=0.83, \mathrm{p}=0.039)$, and number of leaves $(r=0.82, p=0.045)$ also increased as the Ca content increased. Increases in the $\mathrm{Mg}$ content were consistent with increases over time in all analyzed growth variables, including the root length $(\mathrm{r}=0.87, \mathrm{p}=0.025)$, stem diameter $(\mathrm{r}=0.91, \mathrm{p}=0.011)$, total dry mass $(\mathrm{r}=$ $0.83, p=0.038)$, leaf area $(r=0.87, p=0.024)$, number of nodes $(r=0.86, p=0.028)$, stem length $(\mathrm{r}=0.85, \mathrm{p}=0.030)$, and number of leaves $(\mathrm{r}=0.83, \mathrm{p}=0.041)$. However, the contents of these nutrients were positively correlated with each other, with $\mathrm{Ca}$ and $\mathrm{P}$ being $\mathrm{r}=$ 0.94, $\mathrm{p}=0.004, \mathrm{Ca}$ and $\mathrm{Mg} \mathrm{r}=0.91, \mathrm{p}=0.011$, and $\mathrm{P}$ and $\mathrm{Mg}, \mathrm{r}=0.86, \mathrm{p}=0.029$.
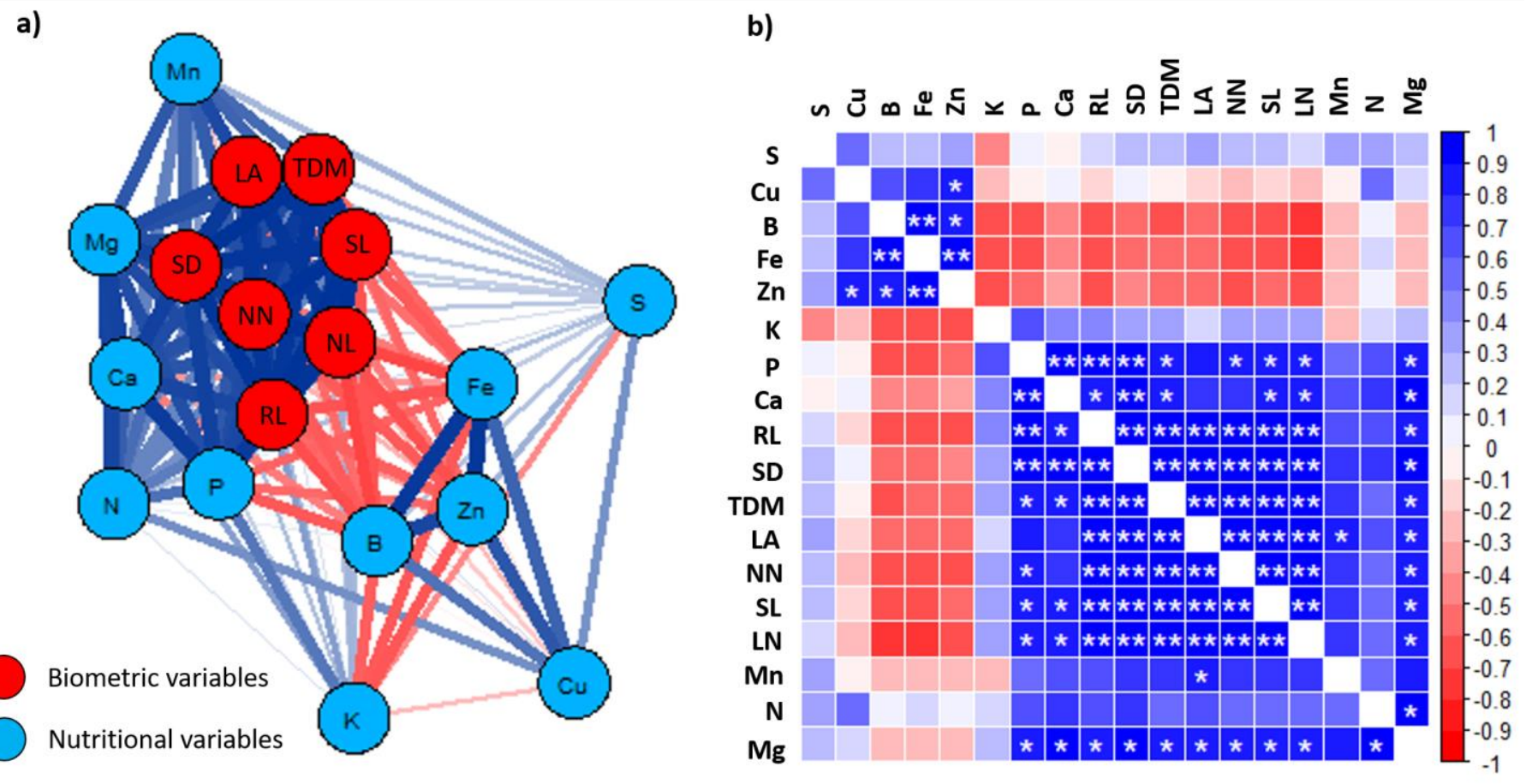

Figure 13. Correlation network (a) and Pearson correlation (b) between total macro and micronutrient contents, considering the values for the leaves, stems, and roots of jatobá (Hymenaea courbaril L.) seedlings at the end of the 180 DAT crop cycle in the nutrient solution. Red and blue lines represent negative and positive correlations, respectively. The line thickness is proportional to the correlation force. $* 5 \%$ probability of significance, $* * 1 \%$ probability of significance. SD - stem diameter; LA- leaf area; SL- stem length; NL- number of leaves; RL- root length; NN- number of nodes; TDM- total dry mass

\section{Discussion}

4.1 H. Courbaril Seedling Leaves Function as Drains Throughout the Initial Development, Although $S$ and Fe Were Accumulated at the Roots

In general, $H$. courbaril plants accumulated dry mass and nutrients linearly throughout their development, thus indicating a perfect adaptation and positive response of these plants to the availability of nutrients via the hydroponic system. A similar profile was determined by Bessa et al. (2016) when analyzing the initial growth of cagaita (Eugenia dysenterica DC.), a 
species native to Brazil, where a linear accumulation of nutrients and dry mass was also observed, with 2.94, 2.84, and $2.82 \mathrm{~g}$ of dry mass for leaves, stem, and roots at 180 DAT.

$H$. courbaril seedlings accumulate more nutrients in the leaves than in other organs during the initial development, thus indicating that the leaves of this species function as efficient drains during this entire phase via labile nutrient availability. Nevertheless, the $S$ content in the roots exceeded the accumulation in the stem during most of the evaluated periods, thus demonstrating the low mobility of this macronutrient from the root to the other organs of this plant. Herschbach et al. (1995a; 1995b) argue that the S load in the xylem is more controlled by aerial demand than by absorption; therefore, we concluded that the high foliar demand of $H$. courbaril, up to 120 DAT, was responsible for reducing the circulation of $\mathrm{S}$ in the stem. In contrast, the phloem must have a considerable capacity to transport $\mathrm{S}$, as the reduction of sulfate occurs mainly in the leaves, and the roots are largely dependent on this transport route for the acquisition of sulfur-containing amino acids (Clarkson et al., 1983; Silva et al., 2003). Therefore, the root requirement for these amino acids, along with the development, may explain the high concentration of root $\mathrm{S}$ observed in $H$. courbaril.

Fe accumulated more in the root than in the stem and leaves of $H$. courbaril seedlings during most assessment periods, which is also related to the poor mobility of this element. Fe is necessary for respiration and photosynthesis, which ensure its participation in the transfer of electrons via reversible redox reactions and in the conversions between $\mathrm{Fe}^{2+}$ and $\mathrm{Fe}^{3+}$ (Kim \& Guerinot, 2007). Under aerobic conditions in the soil, Fe is present in the form of oxides and hydroxides, which are very insoluble, or in the form of organic ferric ion chelates $\left(\mathrm{Fe}^{3+}\right)$. Therefore, the concentration of Fe available in most soils is very low, and plants have developed mechanisms for the mobilization and absorption of this nutrient by the roots (Epstein \& Bloom, 2005).

\subsection{H. Courbaril Seedlings Requirements for Growth, Primarily N and Mn}

The final accumulation of nutrients in $H$. courbaril seedlings indicated that $\mathrm{N}$ is the macronutrient most required by this plant in the early stages of its development. A similar response was observed in the seedlings of Eugenia dysenterica DC. (Bessa et al., 2016). Interestingly, this plant exhibited the same order of macronutrient accumulation determined for $H$. courbaril. For the bromeliads of Aechmea fasciata (Lindley) Baker, Young et al. (2018) also determined that $\mathrm{N}$ is the most required macronutrient because the observed order of accumulation was $\mathrm{N}>\mathrm{P}=\mathrm{K}>\mathrm{Ca}=\mathrm{Mg}>\mathrm{S}$. In fact, $\mathrm{N}$ has been considered as the main essential element for the growth of all plants, especially during the early stages of development (Ohyama \& Sueyoshi, 2010). N is generally available in agricultural soils in the form of nitrate and ammonium. After absorption, the assimilation of $\mathrm{N}$ involves the reduction of nitrate to ammonium and its subsequent incorporation into amino acids. The amino acids, and also nitrate, are transported from root to stem and vice versa (Krapp, 2015).

For micronutrients, Mn was the most accumulated in $H$. courbaril seedlings. $\mathrm{Mn}$ is an essential cofactor in the oxygen evolution complex (OEC) of the photosynthetic machinery, which catalyzes the water split reaction in the photosystem II (PSII). Additionally, although there are also several enzymes involved in the redox system that depend on $\mathrm{Mn}$, including 
superoxide dismutase, catalase, and peroxidase (Yachandra et al., 1996; Schmidt \& Husted, 2019), however, an excess of Mn is toxic to plants. The phytotoxicity of Mn manifests itself in the reduction of biomass and photosynthesis (Santos et al., 2017), as well as in biochemical disturbances, which seem to be intensified in acid soil conditions, such as those of the Cerrado. Excessive concentrations of $\mathrm{Mn}$ in plant tissues can alter several processes, such as enzymatic activity, absorption, translocation, and use of other mineral elements $(\mathrm{Ca}, \mathrm{Mg}, \mathrm{Fe}$, and P), which causes oxidative stress (Ducic \& Polle, 2005; Lei et al., 2007). Therefore, an excess of this element in the tissues of $H$. courbaril suggests that this plant has physiological strategies that ensure its tolerance to this nutrient, which includes the allocation of this metal in different subcellular compartments (for example, vacuoles, endoplasmic reticulum, Golgi apparatus, and cell walls) (Millaleo et al., 2010; Li et al., 2019; Alejandro et al., 2020). This also explains the high content of this micronutrient observed mainly in jatobá leaves.

\subsection{H. Courbaril Seedlings Used $S$ and Cu More Efficiently, Absorbed $N$ and Fe More Efficiently, and Translocated Ca-N and Mn More Efficiently}

This study demonstrated an inversion between content and NUE, i.e., the nutrients that had the highest content values were those with the lowest use efficiencies. $\mathrm{N}$ and Fe, for example, were very cumulative nutrients, but with low use efficiencies. This occurs because the relation of dry mass production increases with its content as the concentration of an element in the plant increases. Although the Pfaffia glomerata plants evaluated for the NAE of N and P possessed a higher $\mathrm{N}$ content than $\mathrm{P}$, they exhibited a lower NUE for N (Serra et al., 2012). Therefore, the macronutrient $\mathrm{S}$ accumulated in low concentrations in the tissues of $H$. courbaril exhibited high NUE, as well as the micronutrient $\mathrm{Cu}$. Despite their low requirements, plants use soil sulphate to synthesize an amino acid, cysteine, which is used for a variety of sulfur-containing compounds, such as glutathione (GSH), methionine, proteins, lipids, coenzymes, and various secondary metabolites (Hawkesford \& De Kok, 2007; Maruyama-Nakashita \& Ohkama-Ohtsu, 2017). However, $\mathrm{Cu}$ participates in cellular physiological processes related to energy production, phospholipid synthesis, iron absorption and transport, and ribonucleic acid production (Alaoui-Sossé, 2004; Alam \& Raza, 2001), but is toxic under high concentrations because it affects the absorption of phosphorus (Feil et al., 2020). Marques et al. (2018) demonstrated that high concentrations of $\mathrm{Cu}$ can affect photosynthetic performance and the root morphology of $H$. courbaril. This explains the low observed concentration of this ion relative to the total dry mass (high NUE).

Contrary to what was observed for NUE, the highest NAE values were observed for $\mathrm{N}$ and Fe. An assessment of nutrient uptake in two guava cultivars, Paluma and 21st Century, also verified $\mathrm{N}$ and $\mathrm{Fe}$ as the nutrients with the highest relative nutrient uptake efficiency (Prado \& Franco 2007). $\mathrm{N}$ is also among the most efficiently translocated nutrients in the tissues of H. courbaril, together with $\mathrm{Ca}$ and $\mathrm{Mg}$, and these three nutrients correspond to the most accumulated in the tissues.

4.4 The Growth of H. Courbaril Seedlings Correlates With the Increase in P, Ca, and Mg Levels Throughout Development

$\mathrm{P}$ is an essential element in determining plant growth and productivity. Owing to the fixation 
of $\mathrm{P}$ in the soil, its availability in the soil is rarely sufficient for optimal plant growth and development. This scenario is different from that induced in a hydroponic system, where the high availability of this element can incur optimal growth. Malhotra et al. (2018) showed that the importance of $\mathrm{P}$ goes beyond its participation as a structural component of nucleic acids, sugars, and lipids. Although this nutrient participates in the development processes of the plant at the cellular and entire plant level (development of roots, stems, flowers, and seeds), the toxicity of $\mathrm{P}$ is rarely reported. Many papers have demonstrated the importance of this nutrient's (P) availability for plant growth, especially for root system development and architecture (e.g., He et al., 2003), whereas Sánchez-Calderón (2006) showed that the unavailability of $\mathrm{P}$ can affect primary root growth.

$\mathrm{Ca}$, however, is transported exclusively by the xylem, and this transport is conducted by the transpiration rate. Because it is not very mobile, this element becomes a component of the walls and cell membranes, thus providing stability and rigidity. St. John et al. (2013) suggested that ca is essential for root development and functionality. However, the rigid leaves of $H$. courbaril, with the abaxial and adaxial glabrous epidermis coated with thick cuticle (Tiago et al., 2020; Jorge et al., 2006), may indicate their functionality as drains for the calcium supply.

Mg plays a key role in many biochemical processes, especially photosynthesis, as it is the central atom of chlorophyll (Maguire \& Cowan, 2002; Willows, 2007). Moreover, Mg is fundamental for a series of enzymatic activities and the synthesis of some proteins (Marschner, 2011; Shaul, 2002). Recent studies have also revealed a role of Mg in relieving stress caused by adverse growth conditions, such as aluminum, $\mathrm{Mn}$ and $\mathrm{Pb}$ toxicity (Bose et al., 2011; Kong et al., 2020; Gransee \& Führs, 2013; Shen et al., 2016), photooxidative damage (Cakmak \& Kirkby, 2008; Hauer-Jákli \& Tränkner, 2019), and heat stress (Mengutay et al., 2013; Siddiqui et al., 2018).

Therefore, this work verifies that $H$. courbaril leaves can function as efficient drains under high nutritional supply, and it demonstrates that $\mathrm{N}$ and $\mathrm{Mn}$ are the most required nutrients by the seedlings of this fruit during its development. However, despite the high accumulation of $\mathrm{N}$ and $\mathrm{Mn}$ observed in the tissues of $H$. courbaril seedlings, the ideal supply of $\mathrm{P}, \mathrm{Ca}$, and $\mathrm{Mg}$ can positively affect its general growth. Therefore, the supply of these nutrients during the production of the seedlings of this species should be considered.

\section{Conclusions}

In this study, seedlings of $H$. courbaril mainly accumulated macronutrient $\mathrm{N}$ and micronutrient $\mathrm{Mn}$ at the end of $180 \mathrm{DAT}$, thus suggesting the tendency of $H$. courbaril to tolerate high concentrations of $\mathrm{Mn}$, which is generally toxic to plants. The highest NUE, however, was observed for $\mathrm{S}$ and $\mathrm{Cu}$, whereas the most efficiently absorbed nutrients were $\mathrm{N}$ (the most accumulated macronutrient) and $\mathrm{Fe}$ (the second most accumulated micronutrient). Although the seedlings efficiently translocated $\mathrm{Ca}-\mathrm{N}$ and $\mathrm{Mn}$ (the most accumulated nutrients), positive effects on growth were correlated with increases in $\mathrm{P}, \mathrm{Ca}$, and $\mathrm{Mg}$ levels, thus signaling the importance of the ideal supply of these nutrients in obtaining healthy seedlings of this species. 


\section{Acknowledgments}

We express our gratitude to IF Goiano Campus Rio Verde, for their technical support and financial assistance, and FAPEG (Foundation to Support Research in the State of Goiás) for the grant, and to CNPq (National Council for Scientific and Technological Development) and Mr. Eli Medeiros for providing the Jatobá seed collection area.

\section{References}

Aguiar, J. C. D., Santiago, G. M., Lavor, P. L., Veras, H. N., Ferreira, Y. S., Lima, M. A., ... Braz-Filho, R. (2010). Chemical constituents and larvicidal activity of Hymenaea courbaril fruit peel. Natural Product Communications, 5(12), 1977-1980. https://doi.org/10.1177/1934578X1000501231

Alam, S. M., \& Raza, S. (2001). Micronutrient fertilizers. Pakistan. Journal of Biological sciences, 4(11), 1446-1450. https://doi.org/10.3923/pjbs.2001.1446.1450

Alaoui-Sossé, B., Genet, P., Vinit-Dunand, F., Toussaint, M. L., Epron, D., \& Badot, P. M. (2004). Effect of copper on growth in cucumber plants (Cucumis sativus) and its relationships with carbohydrate accumulation and changes in ion contents. Plant Science, 166(5), 1213-1218. https://doi.org/10.1016/j.plantsci.2003.12.032

Alejandro, S., Höller, S., Meier, B., \& Peiter, E. (2020). Manganese in plants: from acquisition to subcellular allocation. Frontiers in Plant Science, 11 . https://doi.org/10.3389/fpls.2020.00300

Bailão, E. F. L. C., Devilla, I. A., Da Conceição, E. C., \& Borges, L. L. (2015). Bioactive compounds found in Brazilian Cerrado fruits. International journal of molecular sciences, 16(10), 23760-23783. https://doi.org/10.3390/ijms161023760

Bessa, L. A., Moreira, M. A., Silva, F. G., Mota, C. S., \& Vitorino, L. C. (2016). Growth, nutrient concentration and principal component analysis of Cagaita ('Eugenia dysenterica'DC.) seedlings grown in nutrient solution. Australian Journal of Crop Science, 10(3), 425. https://doi.org/10.21475/ajcs.2016.10.03.p7477

Bose, J., Babourina, O., \& Rengel, Z. (2011). Role of magnesium in alleviation of aluminium toxicity in plants. Journal of Experimental Botany,62(7), 2251-2264. https://doi.org/10.1093/jxb/erq456

Briat, J. F., Gojon, A., Plassard, C., Rouached, H., \& Lemaire, G. (2020). Reappraisal of the central role of soil nutrient availability in nutrient management in light of recent advances in plant nutrition at crop and molecular levels. European Journal of Agronomy, 116, 126069. https://doi.org/10.1016/j.eja.2020.126069

Cakmak, I., \& Kirkby, E. A. (2008). Role of magnesium in carbon partitioning and alleviating photooxidative damage. Physiologia $\quad$ Plantarum, 133(4), https://doi.org/10.1111/j.1399-3054.2007.01042.x

Carvalho, P. E. R. (2003). Espécies arbóreas brasileiras (Vol. 1). Brasília: Embrapa 
Informação Tecnológica. p. 601-607.

Clarkson, D. T., smith, F. W., \& Berg, P. J. V. (1983). Regulation of sulphate transport in a tropical legume, Macroptilium atropurpureum, cv. Siratro. Journal of Experimental Botany, 34(11), 1463-1483. https://doi.org/10.1093/jxb/34.11.1463

Conley, D. J., Paerl, H. W., Howarth, R. W., Boesch, D. F., Seitzinger, S. P., Havens, K. E., ... Likens, G. E. (2009). Controlling eutrophication: nitrogen and phosphorus. Science, 323(5917), 1014-1015. https://doi.org/10.1126/science.1167755

Ducic, T., \& Polle, A. (2005). Transport and detoxification of manganese and copper in plants. Brazilian Journal of Plant Physiology, 17(1), 103-112. https://doi.org/10.1590/S1677-04202005000100009

Epskamp, S., Cramer, A. O., Waldorp, L. J., Schmittmann, V. D., \& Borsboom, D. (2012). qgraph: Network visualizations of relationships in psychometric data. Journal of statistical software, 48(4), 1-18. https://doi.org/10.18637/jss.v048.i04

Epstein, E., \& Bloom, A. J. (2005). Mineral nutrition of plants: Principles and perspectives. (2nd ed). Sinauer: Sunderland. p. 380.

Feil, S. B., Pii, Y., Valentinuzzi, F., Tiziani, R., Mimmo, T., \& Cesco, S. (2020). Copper toxicity affects phosphorus uptake mechanisms at molecular and physiological levels in Cucumis sativus plants. Plant Physiology and Biochemistry, 157, 138-147. https://doi.org/10.1016/j.plaphy.2020.10.023

Gransee, A., \& Führs, H. (2013). Magnesium mobility in soils as a challenge for soil and plant analysis, magnesium fertilization and root uptake under adverse growth conditions. Plant and Soil, 368(1-2), 5-21. https://doi.org/10.1007/s11104-012-1567-y

Hauer-Jákli, M., \& Tränkner, M. (2019). Critical leaf magnesium thresholds and the impact of magnesium on plant growth and photo-oxidative defense: a systematic review and meta-analysis on 70 years of research. Frontiers in Plant Science, 10, 766. https://doi.org/10.3389/fpls.2019.00766

Hawkesford, M. J., \& De Kok, L. J. (2007). Sulfur in plants (Vol. 6). London: Springer.

He, Y., Liao, H., \& Yan, X. (2003). Localized supply of phosphorus induces root morphological and architectural changes of rice in split and stratified soil cultures. Plant and Soil, 248(1-2), 247-256. https://doi.org/10.1023/a:1022351203545

Herschbach, C., De Kok, L. J., \& Rennenberg, H. (1995). Net uptake of sulfate and its transport to the shoot in spinach plants fumigated with $\mathrm{H}_{2} \mathrm{~S}$ or $\mathrm{SO}_{2}$ : Does atmospheric sulfur affect the "inter-organ" regulation of sulfur nutrition?. Botanica Acta, 108(1), 41-46. https://doi.org/10.1111/j.1438-8677.1995.tb00829.x

Herschbach, C., de Kok, L. J., \& Rennenberg, H. (1995). Netuptake of sulphate and its transport to the shoot in tobacco plants fumigated with $\mathrm{H}_{2} \mathrm{~S}$ or $\mathrm{SO}_{2}$. Plant and Soil, 175(1), 75-84. https://doi.org/10.1007/BF02413012 
Hoagland, D. R., \& Arnon, D. I. (1950). The water-culture method for growing plants without soil. Circular. California agricultural experiment station, 347(2nd edit).

Jorge, L. I. F., Mello, A. R. P., Reis, C. M. P. V., \& Ferro, V. O. (2006). Exame microscópico de Ficus enormis (Mart. ex Miq.) Miq.(gameleira) e de Hymenaea courbaril L. var. stilbocarpa (Hayne) Lee \& Langenheim (jatobá). Revista Brasileira de Farmacognosia, 87(3), 85-88.

Khan, M. N., Mobin, M., Abbas, Z. K., \& Alamri, S. A. (2018). Fertilizers and their contaminants in soils, surface and groundwater. Encyclopedia of the Anthropocene, 5, 225-240. https://doi.org/10.1016/B978-0-12-409548-9.09888-2

Kim, S. A., \& Guerinot, M. L. (2007). Mining iron: iron uptake and transport in plants. FEBS letters, 581(12), 2273-2280. https://doi.org/10.1016/j.febslet.2007.04.043

Kong, X., Peng, Z., Li, D., Ma, W., An, R., Khan, D., ... Chen, Q. (2020). Magnesium decreases aluminum accumulation and plays a role in protecting maize from aluminum-induced oxidative stress. Plant and Soil, 1-11. https://doi.org/10.1007/s11104-020-04605-1

Krapp, A. (2015). Plant nitrogen assimilation and its regulation: a complex puzzle with missing pieces. Current Opinion in Plant Biology, 25, 115-122. https://doi.org/10.1016/j.pbi.2015.05.010

Lei, Y., Korpelainen, H., \& Li, C. (2007). Physiological and biochemical responses to high Mn concentrations in two contrasting Populus cathayana populations. Chemosphere, 68(4), 686-694. https://doi.org/10.1016/j.chemosphere.2007.01.066

Li, B., McKeand, S. E., \& Allen, H. L. (1991). Genetic variation in nitrogen use efficiency of loblolly pine seedlings. Forest Science, 37(2), 613-626.

Li, J., Jia, Y., Dong, R., Huang, R., Liu, P., Li, X., ... Chen, Z. (2019). Advances in the mechanisms of plant tolerance to manganese toxicity. International Journal of Molecular Sciences, 20(20), 5096. https://doi.org/10.3390/ijms20205096

Maguire, M. E., \& Cowan, J. A. (2002). Magnesium chemistry and biochemistry. Biometals, 15(3), 203-210. https://doi.org/10.1023/A:1016058229972

Malavolta, E. (1997). Avaliação do estado nutricional das plantas: princípios e aplicações/Eurípedes Malavolta, Godofredo Cesar Vitti, Sebastião Alberto de Oliveira. Piracicaba: Potafos. p. 319.

Malhotra, H., Sharma, S., \& Pandey, R. (2018). Phosphorus nutrition: plant growth in response to deficiency and excess. In Plant Nutrients and Abiotic Stress Tolerance (pp. 171-190). Springer, Singapore. https://doi.org/10.1007/978-981-10-9044-8_7

Marques, D. M., Júnior, V. V., da Silva, A. B., Mantovani, J. R., Magalhães, P. C., \& de Souza, T. C. (2018). Copper toxicity on photosynthetic responses and root morphology of Hymenaea 
courbaril L. (Caesalpinioideae). Water, Air, \& Soil Pollution, 229(5), 138. https://doi.org/10.1007/s11270-018-3769-2

Marschner, H. (2011). Marschner's mineral nutrition of higher plants. Academic press.

Maruyama-Nakashita, A., \& Ohkama-Ohtsu, N. (2017). Sulfur assimilation and glutathione metabolism in plants. In Glutathione in plant growth, development, and stress tolerance (pp. 287-308). Springer, Cham. https://doi.org/10.1007/978-3-319-66682-2_13

Medeiros, P. L., Silva, G. G. C., Oliveira, E. M. M., Ribeiro, C. O., Silva, J. M. S., \& Pimenta, A. S. (2020). Efficiency of nutrient use for biomass production of a Eucalyptus clone as a function of planting density in short-rotation cropping. Australian Forestry, 83(2), 66-74. https://doi.org/10.1080/00049158.2020.1774958

Mengutay, M., Ceylan, Y., Kutman, U. B., \& Cakmak, I. (2013). Adequate magnesium nutrition mitigates adverse effects of heat stress on maize and wheat. Plant and soil, 368(1-2), 57-72. https://doi.org/10.1007/s11104-013-1761-6

Millaleo, R., Reyes-Díaz, M., Ivanov, A. G., Mora, M. L., \& Alberdi, M. (2010). Manganese as essential and toxic element for plants: transport, accumulation and resistance mechanisms. Journal of soil science and plant nutrition, 10(4), 470-481. https://doi.org/10.4067/s0718-95162010000200008

Ohyama, T., \& Sueyoshi, K. (2010). Nitrogen assimilation in plants. Research Signpost, Kerala, India.

Prado, R. D. M., \& Franco, C. F. (2007). Eficiência de absorção de nutrientes em mudas de goiabeira Paluma e Século XXI, cultivadas em solução nutritiva. Revista Brasileira de Ciências Agrárias, 2(4), 275-280. https://doi.org/10.5039/agraria.v2i4a428

Rueden, C. T., Schindelin, J., Hiner, M. C., DeZonia, B. E., Walter, A. E., Arena, E. T., \& Eliceiri, K. W. (2017). ImageJ2: ImageJ for the next generation of scientific image data. BMC bioinformatics, 18(1), 529. https://doi.org/10.1186/s12859-017-1934-z

Sánchez-Calderón, L., López-Bucio, J., Chacón-López, A., Gutiérrez-Ortega, A., Hernández-Abreu, E., \& Herrera-Estrella, L. (2006). Characterization of low phosphorus insensitive mutants reveals a crosstalk between low phosphorus-induced determinate root development and the activation of genes involved in the adaptation of Arabidopsis to $\begin{array}{llr}\text { phosphorus } \quad \text { deficiency. Plant } & \text { 879-889. }\end{array}$ https://doi.org/10.1104/pp.105.073825

Santos, E. F., Santini, J. M. K., Paixão, A. P., Júnior, E. F., Lavres, J., Campos, M., \& dos Reis, A. R. (2017). Physiological highlights of manganese toxicity symptoms in soybean plants: Mn toxicity responses. Plant Physiology and Biochemistry, 113, 6-19. https://doi.org/10.1016/j.plaphy.2017.01.022

Schmidt, S. B., \& Husted, S. (2019). The biochemical properties of manganese in plants. Plants, 8(10), 381. https://doi.org/10.3390/plants8100381 
Serra, A. P., Marchetti, M. E., Vieira, M. C., Robaina, A. D., Nascimento, J. M., Veronesi, C., \& Matos, F. (2012). Eficiência da absorção, translocação e uso de N e P pela Pfaffia glomerata (Spreng.) Pedersen. Revista Brasileira de Plantas Medicinais, 14(2), 255-260. https://doi.org/10.1590/S1516-05722012000200001

Shaul, O. (2002). Magnesium transport and function in plants: the tip of the iceberg. Biometals, 15(3), 307-321. https://doi.org/10.1023/A:1016091118585

Shen, J., Song, L., Müller, K., Hu, Y., Song, Y., Yu, W., ... Wu, J. (2016). Magnesium alleviates adverse effects of lead on growth, photosynthesis, and ultrastructural alterations of $\begin{array}{lllll}\text { Torreya grandis seedlings. Frontiers in Plant } & \text { Science, 7, } & 1819 .\end{array}$ https://doi.org/10.3389/fpls.2016.01819

Siddiqi, M. Y., \& Glass, A. D. (1981). Utilization index: a modified approach to the estimation and comparison of nutrient utilization efficiency in plants. Journal of Plant Nutrition, 4(3), 289-302. https://doi.org/10.1080/01904168109362919

Siddiqui, M. H., Alamri, S. A., Al-Khaishany, M. Y., Al-Qutami, M. A., Ali, H. M., Al-Whaibi, M. H., ... Alharby, H. F. (2018). Mitigation of adverse effects of heat stress on Vicia faba by exogenous application of magnesium. Saudi Journal of Biological Sciences, 25(7), 1393-1401. https://doi.org/10.1016/j.sjbs.2016.09.022

Silva, D. B, Silva, J. A., Junqueira, N. T. V., \& Andrade, L. R. M. (2001). Frutos do cerrado. Brasília: EMBRAPA Informação Tecnológica.

Silva, D. J., Alvarez Venegas, V. H., Ruiz, H. A., \& Sant'Anna, R. (2003). Translocation and redistribution of sulphur in corn and soybean plants. Pesquisa Agropecuária Brasileira, 38(6), 715-721. https://doi.org/10.1590/S0100-204X2003000600007

Sousa, D. D. C. V. D., Bessa, L. A., Silva, F. G., Rosa, M., Vasconcelos Filho, S. D. C., \& Vitorino, L. C. (2020). Morpho-anatomical and physiological responses can predict the ideal period for the transplantation of hydroponic seedlings of Hymenaea courbaril, a neotropical fruit tree. Plants, 9(6), 721. https://doi.org/10.3390/plants9060721

Souza, I. P., Cazetta, A. L., Pezoti, O., \& Almeida, V. C. (2017). Preparation of biosorbents from the Jatoba (Hymenaea courbaril) fruit shell for removal of $\mathrm{Pb}$ (II) and $\mathrm{Cd}$ (II) from aqueous solution. Environmental monitoring and assessment, 189(12), 632. https://doi.org/10.1007/s10661-017-6330-7

St. John, R. A., Christians, N. E., Liu, H., \& Menchyk, N. A. (2013). Secondary nutrients and micronutrient fertilization. Turfgrass: biology, use, and management, 56, 521-541. https://doi.org/10.2134/agronmonogr56.c15

Swiader, J. M., Chyan, Y., \& Freiji, F. G. (1994). Genotypic differences in nitrate uptake and utilization efficiency in pumpkin hybrids. Journal of Plant Nutrition, 17(10), 1687-1699. https://doi.org/10.1080/01904169409364840

Team, R. C. (2020). $R$ : a language and environment for statistical computing. R Foundation for Computing, Vienna, Austria. https://www.R-project.org/. 


\section{Macrothink}

Tiago, P. V., Larocca, D., Silva, I. V. D., Carpejani, A. A., Tiago, A. V., Dardengo, J. D. F. E., \& Rossi, A. A. B. (2020). Caracterização morfoanatômica, fitoquímica e histoquímica de Hymenaea courbaril (Leguminosae), ocorrente na Amazônia Meridional. Rodriguésia, 71. http://dx.doi.org/10.1590/2175-7860202071063

Verzeaux, J., Hirel, B., Dubois, F., Lea, P. J., \& Tétu, T. (2017). Agricultural practices to improve nitrogen use efficiency through the use of arbuscular mycorrhizae: Basic and agronomic aspects. Plant Science, 264, 48-56. https://doi.org/10.1016/j.plantsci.2017.08.004

Wei, T., Simko, V., Levy, M., Xie, Y., Jin, Y., \& Zemla, J. (2017). Package 'corrplot'. Statistician, 56(316), e24.

Willows, R. D. (2007). Chlorophyll synthesis. In The structure and function of plastids (pp. 295-313). Springer, Dordrecht. https://doi.org/10.1007/978-1-4020-4061-0_15

Wootton-Beard, P. (2019). Growing without soil: An overview of hydroponics.

Yachandra, V. K., Sauer, K., \& Klein, M. P. (1996). Manganese cluster in photosynthesis: where plants oxidize water to dioxygen. Chemical Reviews,96(7), 2927-2950. https://doi.org/10.1021/cr950052k

Young, J. L. M., Kanashiro, S., Jocys, T., \& Tavares, A. R. (2018). Silver vase bromeliad: Plant growth and mineral nutrition under macronutrients omission. Scientia Horticulturae, 234, 318-322. https://doi.org/10.1016/j.scienta.2018.02.002

\section{Copyright Disclaimer}

Copyright for this article is retained by the author(s), with first publication rights granted to the journal.

This is an open-access article distributed under the terms and conditions of the Creative Commons Attribution license (http://creativecommons.org/licenses/by/4.0/). 